Pontifícia Universidade $C_{\text {atólica }}$

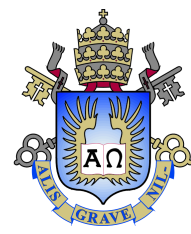

Ruan Valente Staffuzza

\title{
The Effect of Incarceration on Employment: Evidence from Randomly Assigned Court Divisions in Brazi
}

Dissertação de Mestrado

Thesis presented to the Programa de Pós-graduação em Economia da PUC-Rio in partial fulfillment of the requirements for the degree of Mestre em Economia.

Advisor : Prof. Pedro Carvalho Loureiro de Souza Co-advisor: Prof. Claudio Abramovay Ferraz do Amaral 
Ruan Valente Staffuzza

\section{The Effect of Incarceration on Employment: Evidence from Randomly Assigned Court \\ Divisions in Brazi}

Thesis presented to the Programa de Pós-graduação em Economia da PUC-Rio in partial fulfillment of the requirements for the degree of Mestre em Economia. Approved by the Examination Committee.

Prof. Pedro Carvalho Loureiro de Souza

Advisor

University of Warwick -

Prof. Claudio Abramovay Ferraz do Amaral

Co-advisor

Departamento de Economia - PUC-Rio

Prof. Gustavo Maurício Gonzaga

Departamento de Economia - PUC-Rio

Prof. Francisco Junqueira Moreira da Costa

Escola Brasileira de Economia e Finanças - FGV/EPGE

Rio de Janeiro, August, 9th, 2019 
All rights reserved.

\section{Ruan Valente Staffuzza}

B.A., Economics, Universidade de Brasília (UnB), 2015

Bibliographic data

Valente Staffuzza, Ruan

The Effect of Incarceration on Employment: Evidence from Randomly Assigned Judges in Brazil / Ruan Valente Staffuzza; advisor: Pedro Carvalho Loureiro de Souza; coadvisor: Claudio Abramovay Ferraz do Amaral. - Rio de janeiro: PUC-Rio, Departamento de Economia, 2019.

v., 60 f: il. color. ; $30 \mathrm{~cm}$

Dissertação (mestrado) - Pontifícia Universidade Católica do Rio de Janeiro, Departamento de Economia.

Inclui bibliografia

1. Economia - Teses. 2. Encarceramento;. 3. Emprego;. 4. Crime. I. Carvalho Loureiro de Souza, Pedro. II. Abramovay Ferraz do Amaral, Claudio. III. Pontifícia Universidade Católica do Rio de Janeiro. Departamento de Economia. IV. Título. 


\section{Acknowledgments}

First, I would like to thank the absurdity of existence itself: the inevitable succession of related events that carried us from the unknown to here and now. By some means, despite all my dimness, life have gifted me the contact with amazing people, who have aided in the completion of the present work, and much more.

This research would never be possible without my mother and my father, who are a source of power, inspiration and direction. I also thank for my sister, Raissa, my brother, Marcelo, and other family members who have supported me along the way.

Many thanks to my advisor, Prof. Pedro C. L. Souza, for his guidance, encouragement and dedication, and Prof. Cláudio Ferraz for his helpful insights and support. I thank Prof. Gustavo Gonzaga for enabling access to RAIS database, which was necessary for this work. My gratitude to all other PUCRio professionals that facilitated my learning during Master

For all those students who spend time in our "favelinha" laboratory it was great sharing it during the last years, special thanks for those who gave valuable contributions to my work.

I gratefully acknowledge all at institutions that provided financial support for the present study. This study was financed in part by the Coordenação de Aperfeiçoamento Pessoal de Nível Superior - Brasil (CAPES) - Código de Financiamento 001. In addition, I thank PUC-Rio and Fundação Carlos Chagas Filho de Amparo à Pesquisa do Estado do Rio de Janeiro (FAPERJ).

Finally, I feel the urge to somehow grant appreciation for all that, despite not having family or professional obligations, spent their time with me, delighting my journey during spare time. Without the relief of having my silly and deep complaints heard, the joy of stimulating conversations and the atmosphere of loving and being loved, none of my effort would have meaning. 


\section{Abstract}

Valente Staffuzza, Ruan; Carvalho Loureiro de Souza, Pedro (Advisor); Abramovay Ferraz do Amaral, Claudio (Co-Advisor). The Effect of Incarceration on Employment: Evidence from Randomly Assigned Court Divisions in Brazi Rio de Janeiro, 2019. 60p. Dissertação de mestrado - Departamento de Economia, Pontifícia Universidade Católica do Rio de Janeiro.

In Americas imprisonment policy has increasingly been adopted to deal with law offenders, and a steep increase in countries incarceration rates has been observed since the 1980s. Nevertheless, we still lack evidence on how such penalty affects labour market outcomes of ex-inmates, specially in developing countries. This work exploits the variation in detention tendencies of randomly-assigned judges as an instrumental variable to estimate the impacts of incarceration on formal labour market outcomes. We construct a unique panel dataset merging data from São Paulo city court, containing judicial sentence information with formal employment records. Essentially, we compare individuals who were sentenced to prison with those who were not. We find that the immediate negative impact of sentence to prison on employment tends to fade over time and disappear after release.

\section{Keywords}

Incarceration; Employment; Crime 


\section{Resumo}

Valente Staffuzza, Ruan; Carvalho Loureiro de Souza, Pedro; Abramovay Ferraz do Amaral, Claudio. O Efeito de Encarceramento na Empregabilidade: Evidencia Baseada no Sorteio de Varas Criminais no Brasil . Rio de Janeiro, 2019. 60p. Dissertação de Mestrado - Departamento de Economia, Pontifícia Universidade Católica do Rio de Janeiro.

Nas Américas a política de aprisionamento tem sido crescentemente utilizado como uma forma de lidar com infratores da lei, sendo observado um aumento vertiginosos nas taxas de encarceramento dos países a partir da década de 80 . Apesar disso, existe pouca evidencia sobre quanto esse tipo de penalidade afeta os resultados do mercado de trabalho de ex-internos, especialmente no contexto de países subdesenvolvidos. Esse trabalho explora o sorteio dos processos entre juízes das varas criminais, e seus níveis de severidade distintos, como variável instrumental para estimar o efeito do encarceramento nos resultados do mercado de trabalho formal. Foi construída uma base de dados que combinou as sentenças de primeira instancia as varas criminais da cidade de São Paulo, Brasil, com o registro formal de emprego da RAIS. Encontramos que o efeito negativo imediato de uma sentença condenatória ao regime fechado ou semi-aberto diminui ao longo do tempo, desaparecendo depois que o indivíduo foi solto.

\section{Palavras-chave}

Encarceramento; Emprego; Crime 


\section{Table of contents}

$\begin{array}{lr}\text { List of figures } & 8\end{array}$

$\begin{array}{lr}\text { List of tables } & 9\end{array}$

$\begin{array}{llr}1 & \text { Introduction } & 11\end{array}$

2 Institutional Context $\quad 15$

2.1 Justice and Prison Systems in São Paulo State 15

$\begin{array}{lll}2.2 & \text { Assignment of Cases to Judges } & 18\end{array}$

3 Data 20

3.1 Data and sample selection 20

3.2 Descriptive statistics 21

4 Research Design $\quad \mathbf{2 6}$

4.1 Prison Treatment 26

$\begin{array}{lll}4.2 & \text { Released Treatment } & 27\end{array}$

4.3 Instrumental Variable Approach 27

$\begin{array}{lll}4.4 & \text { First Stage } & 29\end{array}$

4.5 Instrument Validity 30

5 Results $\quad 34$

5.1 Main results 34

5.2 Heterogeneity of the effect among crime types 37

5.3 Robustness check: restrict to less frequent names 40

6 Conclusions 43

$\begin{array}{lll}7 & \text { Bibliography } & 46\end{array}$

A Statistics of São Paulo's Penitentiary System 48

B Independence of the instrument $\quad 50$

C Monotonicity $\quad 52$

$\begin{array}{lll}\text { D } & \text { First stage results } & 53\end{array}$

E Extra results - Figures $\quad 59$ 


\section{List of figures}

Figure 3.1 Employment rate over time relative to trial 25

Figure 4.1 Histogram of instruments 29

Figure 5.1 Overall DD results 35

Figure 5.2 DD differences in judgement effect. 35

Figure 5.3 Overall DD results - crime types $\times$ time fixed effects 36

$\begin{array}{lll}\text { Figure 5.4 Overall DD-IV results } & 37\end{array}$

Figure 5.5 Robbery DD results 38

Figure 5.6 Drug-related DD results 38

$\begin{array}{lll}\text { Figure 5.7 } & \text { Theft DD results } & 39\end{array}$

Figure 5.8 Robbery DD-IV results 39

Figure 5.9 Drug-related DD-IV results 40

Figure 5.10 Theft DD-IV results 41

Figure 5.11 Less common name - DD results 41

Figure 5.12 Less common name DD-IV results 42

Figure E.1 Handling of stolen goods DD results $\quad 59$

$\begin{array}{lll}\text { Figure E.2 } & \text { Firearm possession DD results } & 59\end{array}$

Figure E.3 Handling of stolen goods DD-IV results 60

Figure E.4 Firearm possession DD-IV results 60 


\section{List of tables}

Table 3.1 Descriptive statistics by crime type 23

Table 3.2 Descriptive Statistics 24

Table 4.1 First stage results $\quad 31$

Table 4.2 Correlation between instruments and pre-trial characteristics 33

Table A.1 Information on São Paulo State prison population 49

Table B.1 Correlation between instrument and pre-trial characteristics - Crime Types $\quad 51$

Table C.1 Monotonicity assumption test $\quad 52$

$\begin{array}{lll}\text { Table D.1 First stage results - Robbery } & 54\end{array}$

Table D.2 First stage results - Drug-related $\quad 55$

Table D.3 First stage results - Theft $\quad 56$

Table D.4 First stage results - Stolen goods 57

Table D.5 First stage results - Firearm 58 


\section{List of Abreviations}

\section{MP - Ministério Público}

TJSP - Tribunal de Justiça de São Paulo

DD - Differences-in-differences

DD-IV - Instrumental variable differences-in-differences

CI - confidence interval

RAIS - Relação Anual de Informações Sociais

USA - United States of America 


\section{Introduction}

Imprisonment has been a choice around the world to punish law offenders, such as murders, drug dealers and thieves. This kind of policy has increasingly been imposed during the last decades, especially in USA and Latin America. Incarceration rate, the number of people in jail for each group of 100,000 inhabitants, has increased from 220 to more than 700 in the last 38 years in the United States of America (USA). In Brazil, the rate has more than doubled during the last two decades, going from 132 to 324 between the years 2000 and 2018 .

Since security and enforcement of socially desired behaviour are concerns in every society, there is a need to understand the outcomes of a policy designed for this purpose. Besides deterrence effect (imposing a cost for those who do not follow the law) and incapacitation effect (removal from social conviviality avoiding crimes during detention), there is a concern on how well integrated in society ex-inmates are, in particular what are their chances of engaging in a legitimate work after prison.

Theory predicts mechanisms responsible for either increasing or decreasing the chances of employment after prison. Positively, prison could update beliefs on likelihood of being caught and associated costs of being in prison. It could increase human capital by encouraging education and job training. Negatively, the exposure to violence environment and connections to crime network might promote criminal market activities, deteriorate mental health and human capital, and restrict opportunities due to stigmatisation. Prevalent mechanisms may vary depending on the prison system and social conditions. For example, poor prison conditions are responsible for diminishing mental health and increase violent behaviour and the dominance of criminal factions might strengthen inmates connections with crime network.

Previous empirical research on the effects of prison on employability comes mostly from USA and Europe. Evidence from developed countries should take into account their specific characteristics regarding human capital accumulation, labour market conditions and criminal justice system. Research from a developing country is prone to shed light on the theme from an innovative perspective, therefore the distinctive conditions related to Brazil 
and other developing countries can substantially defy the existing outcomes of the literature.

Any assessment of the causal effect of imprisonment on any outcome must properly address selection on unobservables: two groups, those convicted to prison penalty and those acquitted, might differ in characteristics that are correlated with future employment outcomes. We propose two methods to deal with this issue: differences-in-differences and instrumental variable approach.

Our instrumental variable for judgement result was constructed based on the random allocation of cases among judges and the the eminent heterogeneity in propensity for incarceration among judges. It allows for a new comparison: those defendants judged by severe or lenient judges. Suppose two individuals who committed a similar crimes in similar circumstances and are randomly allocated to distinct judges. Since in my sample some judges incarcerate around $40 \%$ of their defendants, while other reach $70 \%$, this two individuals might have markedly different sentences. One individual might be imprisoned while the penalty for the other might be converted into community work. For this comparison to identify the correct effect, allocation of judges must be certainly random, therefore, unobservable characteristics must be balanced across groups.

Our work is the first to use judicial sentences made available online by Tribunal de Justiça do Estado de São Paulo (TJSP), the São Paulo state court, in Brazil. We scrapped decisions from their website and created and algorithm to read textual information. Our work yielded 64,722 defendants judged sometime during years 2011 to 2017 and their criminal sentence results. We searched for each defendant in RAIS, administrative record of formal labour market, during the years of 2010 to 2017.

In order to detect the effect of imprisonment we, first, explore defendant and time fixed effect, analysing how being sentenced affects individual dynamics of employment. In this setting, we present how the effect of being convicted differs from those acquitted in respect to the time of judgement. To make sure our results are not being driven by differences in tendencies prior to trial between those to groups, we also implement a instrumental variable approach, exploiting the random assignment of criminal cases to judges, who differ systematically in their stringency in sentencing defendants to prison.

We find that, first, during the year of judgement, individual face a negative impact on employment. These negative effects of prison on employment happens probably due to lack of formal work available for inmates. However, point estimates of this immediate negative effect ranges from 1.5 to 3 percentage points, quite small if compared to the mean employment rate in our 
sample, which is $17 \%$. This small effect may be explained by: i) imperfect identification of defendant work record, which is made solemnly by defendant name; ii) that we attest only when the defendant was sentenced to prison, not actually went to prison.

We also find that, after a certain time, the negative effects of being sentenced to prison on employment fade away. Point estimates indicate reversion of the negative effect by the second year after prison sentence, however we were not able to reject the hypothesis that it was equal zero, mainly because instrumental variable approach resulted in high standard error.

These effects, of first negative shock on employment followed by reversion to zero in maximum of three year, are fairly robust. Using the baseline sample, these are not rejected by instrumental variable method and are captured by differences-in-differences (DD). When interpreting such results we should be concerned with the lack of precision arising from instrumental variables approach and the lack of parallel trends, needed for DD. Although parallel trends condition were not met, DD results shall be interpreted as indicative. DD results for the effect of prison are slightly positive two years after trial, or, using a prediction on the release time, one year after release. Since these DD results go in the opposite direction of the immediate negative effect, we interpret it sparingly as suggestive of no effects of prison after release.

We also explored heterogeneity of these effects according crime type and found that our results were mostly driven by robbery and drug-related crimes. We find no consistency on statistically significant effects for defendants accused of theft, handling of stolen goods and firearm possession. This may be due to the fact that prison is less enforced for such less severe misdemeanours.

Our work is related to empirical research that tried to isolate the effects of prison on future employment. Since the measurement of this effect could reflect unobserved differences between criminals and noncriminals, first the literature studied how this relations behaved over time. Grogger (1995) invested in a fixed-effects model, comparing labour market outcomes of individuals who have been first arrested after and before the examination of their employment status. He finds that the negative effects of arrest and prison on employment are modest in magnitude and fairly short-lived.

Our findings contribute specially the recent and more sophisticated literature, that used judge stringency as instrumental variable. Three of these studies use data from USA, but results are mixed. Kling (2006) was the first to use the method and found no evidence of adverse labour market consequences of longer incarceration length. Whereas, Aizer and Jr. (2015), studying juveniles find that incarceration resulted in: substantially lower high 
school completion rates; worse labour market outcomes; and higher adult incarceration rates. Mueller-Smith (2015) reports that incarceration increases recidivism rates, and worsens labour market outcomes. Using data from Norway, Bhuller et al. (2016) linked several administrative data sources and constructed a panel dataset containing complete criminal records and labour market outcomes of every Norwegian citizen. In contrast, there, prison raised employment and earnings while discouraging further criminal behaviour. Their results are mostly driven by changes in the behaviour of individuals who were not working prior to incarceration.

Using data from Argentina, Di Tella and Schargrodsky (2013) studied the effect of electronic monitoring in comparison to prison and find negative effects on recidivism, which translates into criminogenic impact of prison if compared with lighter penalties. That can be interpreted as a possible negative impact of prison on employment. To the best of our knowledge, Di Tella and Schargrodsky (2013) is the only published study that proposes a meticulous empirical investigation on the criminogenic effect of prison using data from developing countries. There are published works attempting to discuss this matter considering the Brazilian background, but those are based on historical investigation, studying, for example, the differences in social profile of repeat and non-repeat offenders. ${ }^{1}$

Our work is organised as follows: the next section describes the context of justice and prison systems, while section 3 explains the data source and sampling. The empirical strategy is described in section 4 , results are displayed in section 5 and we conclude in the last section.

\footnotetext{
${ }^{1}$ These works are strongly influenced by Michel Foucault's sociology and philosophy. By interpreting the social profile of repeat and non-repeat offenders in São Paulo State prisons, Adorno and Bordini (1989) finds that non-repeat offenders tend to be more subject to punitive action, obeying and believing in judicial effectiveness. That suggest that for some group, prison may have restorative effects. In contrast, Barros (2016), while assessing the expansion of São Paulo State's prison population during the last three decades, asserts a failure of repressive criminal policies, but noticing the recent diversification of disciplinary regimes and inclusion of care programs for ex-inmates and their families.
} 


\section{2}

\section{Institutional Context}

In this section, we describe the institutional context in which our research is based on. We start by reviewing key aspects of the criminal justice system in São Paulo State, Brazil and documenting how criminal court cases are randomly assigned to judges.

\section{1}

\section{Justice and Prison Systems in São Paulo State}

The present work deals with crimes under State jurisdiction, more specifically the ones of the Court of Justice of the State of São Paulo. ${ }^{1}$ The procedure for the inquiry, judgement and enforcement of sentences in Brazil is complex and full of nuances, and following we will describe as the most common procedures, aiming to understand the general panorama.

The police has the duty to ensure public order and investigate crimes. Each police station registers and establishes crimes in its area of circumscription, interrogating witnesses, interviewing the detainee and requesting information, exams, expert examination, thus producing a police inquiry. The starting point for most of the police inquiries are flagrante delicto arrest, which is possible when someone is caught while perpetrating a crime or immediately after it. After flagrante delicto arrest, police has 24 hours to send a report of detention to the Court. Then one custodial judge decides if pretrial detention is necessary. Statistics about São Paulo State prison population, presented by the report on 'Crime, Public Safety and Institutional Performance in São Paulo' (Bergman et al., 2013), show how dependent criminal case resolution is on flagrante delicto. There, $78 \%$ of prisoner accused of theft and $82 \%$ of drug related cases were detained on the day that they committed the crime. ${ }^{2}$

In possession of police enquiry report, prosecutor decides whether to demand more investigation, to dismiss the case or to bring a formal charge against the suspect. If a lawsuit is filed, the case is sent to the first instance of

\footnotetext{
${ }^{1}$ The criminal justice system in Brazil is divided between Federal and State. Federal courts judge cases of federal interest as smuggling, currency evasion and money laundering and States are responsible for crimes such as homicide, robbery, theft, rape, threat, drug trafficking, illegal possession of weapons.

${ }^{2}$ We do not have information if the cases we are handling have started with flagrante delicto arrest or if the defendant was under custody while being judged.
} 
court decision, where the case will be followed by a single judge, the same one that oversees further investigation. The choice of this single judge responsible for the case must be made by the court following the principle of randomness. Further explanation on the process of assignment of cases to judges is given in Section 2.2.

After that, the defendant is convened and presents an initial written defence reply, on that ground the judge can summarily acquit the defendant. If not, a hearing is appointed when the defendant, victims, witness and expert witness testify. Also during the hearing the prosecutor and the defence make their closing arguments, orally, and at the end the judge should pass the sentence, acquitting or convicting the defendant.

For those condemned, a range of penalties is foreseen to be applied concurrently or in lieu of a prison sentence. ${ }^{3}$ A fundamental concept underlying Brazil's penal code is that of the individualisation of penalties: judges should consider defendant's individual circumstances when prescribing the sentence. According to the law, the judge must take into account 'the guilt, background, social conduct, personality of the agent, the reasons, circumstances and consequences of the crime, as well as the behaviour of the victim' (Brasil, 1940). This allowance for the use of subjective criteria when deciding the penalty severity, though observing maximum and minimum limits of sentence dosage imposed by law, opens space for heterogeneity in judge decision.

The Brazilian prison system was conceived to be a progression system, with three different disciplinary regimes: closed, semi-open, and open. After serving a determined amount of time in one regime performing 'good prison behaviour' the prisoners qualify to be transferred to a less restrictive regime and ultimately may be released entirely. If the prisoners commit a serious misconduct they may be subject to regime regression. Following, we described each regime, first its legal status and how it has been implemented in São Paulo State.

The closed regime is intended for recidivists or those sentenced to eight years of prison or more. There, prisoners are confined in a penitentiary and may be offered work inside the unit, external work is admissible only for public works and practically never available. Semi-open regime is intended for nonrecidivist with sentences greater than four and less than eight years.

In semi-open, by law, the individual must serve the sentence in an agricultural or industrial colony, working. In addition, they are allowed temporary exit from the prison for external work or education. However, in practice,

\footnotetext{
${ }^{3}$ Those penalties are: (i) fine, (ii) loss of assets and values, (iii) provision of services to the community or to public entities, (iv) participation in an educational lecture, and (v) temporary limitation of weekend or other rights.
} 
conditions are not as the law dictates: there are only few agricultural and industrial colonies. Not all prisoners who have the right to semi-open are able to find vacancies in proper establishments and it is common for prisoners of the semi-open to be in the same penitentiary as those of the closed (Godoi, 2016). In 2016, inmates who lined up for a semi-open place represent about a quarter of the prison population serving time under the regime (Arcoverde, 2016). ${ }^{4}$

Non-repeat offenders, with penalties of less than two years of custody should be sent to open regime: custodial sentence enforcement in a lodge house with absence of physical obstacles to escape. ${ }^{5}$ However, due to the lack of the lodge houses or other facilities intended for open regime in SP, nobody is serving on it, those who would be submitted to open regime usually serve sentence under house arrest. In 2014, Brazil's National Council of Justice (Conselho Nacional de Justiça, CNJ) reported that over 92 thousands convicts were domiciliary prisoners in SP (Brasil, 2014).

How each regime is implemented shows that effectively only those sentenced to closed and semi-open regimes can be counted as being sentenced to prison. However, after being judged by the lower court, any party to the proceedings (defendants or MP) has the right to appeal the decision. If neither party appeals to the sentence provided, or when ceased the appellation phase, the prison sentence can be enforced.

Going to jail in this penitentiary system possibly means stepping into places with presence of: overpopulation, criminal faction control, rebellions and violence (Biondi et al., 2009; Dias, 2011). The general conditions of education and work policies are also problematic. While the prison population São Paulo State has low level of education, about $50 \%$ have less than primary school, only $10 \%$ of inmates engage in education activities and only $13 \%$ are working (Brasil, 2017). ${ }^{6}$

However, São Paulo State has created within its Secretariat of Penitentiary Administration a "Coordination of Social Reintegration and Citizenship", which, through its "Centers for Attention to the Egress" (CAEFs), conducts programs for the reintegration and inclusion of graduates in society and the labour market. There are currently $46 \mathrm{CAEFs}$ in the state who provided more than 600,000 attendances to ex-inmates between 2010 and 2017, and 55,053

${ }^{4}$ Table A.1 reported that only $13 \%$ of inmates in São Paulo State are involved in labour activities. That is just a hint of how many in our dataset had opportunity to work while in prison. The State rate does not perfectly reflect those of our data, since we deal with cases located in São Paulo City and judged after 2011.

${ }^{5}$ In this regime, the offender must work outside the institution, attend a course or exercise another authorised activity, staying in building during night and on days off.

${ }^{6}$ This information, and others, are displayed in Table A.1, included in Appendix A, presents other statistics on the prison population of São Paulo State, extracted from Brasil (2017). 
sentenced to the semi-open regime received vocational training between 2010 in 2018, however, in this period only 1,422 got jobs with the help of the coordination. Dispersed information on these programs are available in Brasil (2019).

Although prison conditions are not ideal, in Brazil, there are many rules allowing the defendant to spend less time in jail than the one provided in the initial sentence. First, pretrial detention time must be deducted from sentence time. There is also the possibility of remission of the sentence for study time and prison work. Every 3 days working or 12 hours studying results in less one day of grief.

In addition to these, the Brazilian Penal Code provides for the possibility of 'conditional release', early return of freedom to the sentenced. To do so, it is necessary to comply with certain requirements, which are: been sentenced to more than two years; partially served the sentence (the share depends on class of crime severity and the criminal history of the individual); behave well during the enforcement period. All these factors are evaluated by the judge of penal enforcement in response to the request of the defence.

Finally, the Penal Code provides the possibility of presidential 'indult' as one of the means of extinguishing the convict's punishment sooner. In order to deal with the overcrowded prisons, lately, every year the President of the Republic have used his prerogative and assigned some kind of 'indult'. Like in conditional release, the 'indult' is granted only to prisoners who meet a series of requirements, which demand completion of increasingly portion of prison time, depending on the seriousness of the crime and the history of recidivism.

\section{2}

\section{Assignment of Cases to Judges}

The first criteria used to decide who is the judge responsible for each case is the place where the alleged crime was committed. When this location is not known the jurisdiction will be established by the defendant's domicile. São Paulo State is divided in jurisdiction counties and depending on the size, a county can have more than one criminal judge.

All of our cases were located in São Paulo City county. In the jurisdiction of São Paulo City there are 62 criminal judge seats able to take over a criminal case. ${ }^{7}$ A case is, then, distributed among those seats and it means that the only judge allowed to follow the case is the one assigned to the seat. Magistrates

${ }^{7}$ There were 31 criminal court offices (Varas Criminais) where magistrates carry out their activities. Each office has two judge seats, and there the two professionals share space and personnel. In 2015 TJSP created a new office, and two new judge seats, but any case judged by this office were not considered in our database. 
might exchange seats, moving to higher instances, other locations or law themes different from criminal. The judge responsible for the case is the one holding the seat. ${ }^{8}$.

The Brazilian Penal Code (Código de Processo Penal) dictates that whenever there is more than one judge seat competent to judge a specific case it must be distributed randomly among those seats. In practice, cases are assigned by a software to the judges on a mechanical, rotating basis based on the date a case is received and considering the workload of each judge seat. The details on how the workload is distributed keeping the random assignment of judges are not available. It is in the rules of TJSP that the lot procedure is defined internally and is undisclosed (Brasil, 1999). ${ }^{9}$

${ }^{8}$ That's why in our database, the sentences were pronounced by 179 distinct the judges, while there are only 62 seats.

${ }^{9}$ Even though the cases belong to the seat, not a judge, in our database we only have information on the judge and the office (vara criminal) responsible for the case. Therefore, hereafter we are going to call the assignment of cases to seats as the assignment of cases to judges. 


\section{Data}

In this section we outline how the dataset used was constructed and offer some statistics, briefly describing the data.

\section{1}

\section{Data and sample selection}

We merged data from two sources putting together a completely new case-level dataset with information on 64,722 defendant, who where judged in São Paulo City circumscription between the years of 2011 and 2017, and their formal job record. Our source on judicial sentences data are the website of São Paulo Court of Justice (TJSP) and the information on employment taken from Relação Anual de Informações Sociais (RAIS).

In 2011, following the beginning of digitisation of judicial cases, TJSP started disclosing publicly, via Internet, judicial sentences from the courts of first instance. Supposedly, as declared by the Court, all the decisions in the merit are available online (de Franco et al., 2015). Information of interest were retrieved from sentence text using a computer tool called 'regular expressions', which enables writing patterns to be identified. We extracted the following information from sentences: i) type of crime (classified by the court); ii) judge name; iii) legal case start date; iv) trial date ; v) trial outcome; vi) defendant name.

We limited the analysis to five types of crimes available, which corresponded to approximately $84 \%$ of initial observations: robbery; drug-related ; theft; handling stolen goods; and firearm possession. ${ }^{1}$ The classification of crime type was made by Court's personnel, and follows a national standard. The only change made by us was to merge 'simple theft' with 'qualified theft' to increase predictive power of heterogeneous effects.

In order to reliably use 'regular expressions' tool it was necessary to limit the analysis to sentences that only had one defendant, thus leaving 64,722 cases or defendants, $65 \%$ of the initial observations. The reference to our panel might be either the number of defendants or the number of cases since the

\footnotetext{
${ }^{1}$ In fact, 'firearm possession' encompasses any violation of Law No. 10,826/03, known as
} the Statute of Disarmament, that restricts the possession, commerce, and carrying of guns. 
only available identifier is name and it was not possible to identify when the same individual was prosecuted in more than one case.

We collected 64,722 decisions referring to police cases registered in São Paulo City, São Paulo State, Brazil. Each case was judged by one of the 179 in our dataset. Table 3.1 Panel A describes crime types and trial results frequencies. We classify as acquitted all those judged not guilty, sentenced to alternative penalties or open regime. Those sentenced to closed and semi-open regime are considered convicted, sentenced to prison.

The other database used is RAIS, an administrative database collected by the Ministry of Labour containing information on all the formal labour contracts, including workers identification numbers, that allows the same worker to be followed over time. ${ }^{2}$ RAIS provides information on workers (education, race, age) as well as the characteristics of the employment relationship as average salary.

Defendant's full name is the only identifier available on judicial database and the merger with RAIS was made only by that medium, which is is not enough to ensure perfect identification. Homonyms are not rare and we can expect mistakes. Sometimes we will find work record for individuals who in fact were not working and others times we might match the wrong person. In our dataset some defendants had up to 1,740 workers with the same name as him, in these cases we chose the corresponding worker randomly. For some of our tests we divide defendants in two groups, with less frequent name or with more frequent name. Are considered with less frequent name those who had maximum of one workers with the same name.

\section{2}

\section{Descriptive statistics}

Table 3.1, Panels A and B present statistics for our court database, crosssectional data containing 64,722 defendants. Panel A describes crime types and trial results frequencies. Panel B presents other statistics of the court database.

There we can find why the prison system is filed with about $72 \%$ of prisoners prosecuted for both drug-related and robbery crimes (as showed in Table A.1). Roughly $60 \%$ percent of our cases are related to drug or robbery, and those accused of robbery and drug-related crimes are more likely to be sentenced to prison and have larger prison time sentence. In our full sample, approximately $57 \%$ were convicted to prison and the mean prison time is 2.5 years, while $75 \%$ and $72 \%$ of robbery and drug-related cases, respectively, were

${ }^{2}$ Firms that do not fill the forms, or provide inaccurate report can be fined by the government. 
convicted to prison and had mean prison sentence of 4.15 and 3.27. These statistics are justified by the fact that, among the types of crime selected, these two kinds of crimes are more serious according to Brazilian legal system.

In Panel C of Table 3.1 presents statistics using the full panel: merged court observations and employment history. It shows that the employment rate is greater for those processed by firearm possession.

Table 3.2 differentiate statistics for those acquitted and convicted. Panel $\mathrm{A}$ is restricted to the data available on the Court sample, cross-sectional data containing one observation by defendant. Since those defendants incarcerated before trial usually have their cases handled with more celerity, the process duration is different across the two groups. Panel $\mathrm{B}$ of Table 3.2 shows figures for the full panel, merged court observations and employment history. Overall formal employment rate is $17 \%$ for and about $54 \%$ of defendants has being employed during during 2010-2017. Although the difference between the two groups are statistically different with $95 \%$ of confidence, they are quite small, reflecting the noisy measurement of employment. Panel $\mathrm{C}$ presents statistics just for those employed: schooling, race, age, average wage. As in Panel B, statistics are quite similar among the two groups, being smaller the age, greater the years of schooling and the proportion of blacks among those convicted.

Figure 3.1 presents how the employment rate varied across periods relative to trial and across acquitted and convicted. The simple comparison between groups shows that those sentenced to prison are less likely to be working, specially one year after trial. This difference between the two groups fades over time. The difference between the two groups, specially before treatment, evidence how difference in unobservables are relevant and justify why we should not use OLS. 
Table 3.1: Descriptive statistics by crime type

\begin{tabular}{|c|c|c|c|c|c|c|}
\hline & \multicolumn{5}{|c|}{ Crime Type } & \multirow[b]{2}{*}{ Total } \\
\hline & Robbery & Drug & Theft & $\begin{array}{l}\text { Stolen } \\
\text { goods }\end{array}$ & Firearm & \\
\hline \multicolumn{7}{|c|}{ Panel A: Sentence Result } \\
\hline Closed regime & $56.3 \%$ & $66.6 \%$ & $15.6 \%$ & $14.8 \%$ & $17.1 \%$ & $42.4 \%$ \\
\hline Semi-open regime & $19.1 \%$ & $5.5 \%$ & $18.0 \%$ & $14.7 \%$ & $10.4 \%$ & $14.4 \%$ \\
\hline Open regime & $9.8 \%$ & $4.1 \%$ & $16.5 \%$ & $13.9 \%$ & $8.6 \%$ & $10.3 \%$ \\
\hline Alternative & $2.3 \%$ & $11.8 \%$ & $31.0 \%$ & $38.4 \%$ & $47.0 \%$ & $18.1 \%$ \\
\hline Not guilty & $12.4 \%$ & $12.0 \%$ & $18.9 \%$ & $18.3 \%$ & $16.8 \%$ & $14.7 \%$ \\
\hline Total & $100 \%$ & $100 \%$ & $100 \%$ & $100 \%$ & $100 \%$ & $100 \%$ \\
\hline \multicolumn{7}{|c|}{ Panel B. Mean variables: court sample } \\
\hline Convicted $=1$ & $\begin{array}{c}0.75 \\
(0.43)\end{array}$ & $\begin{array}{c}0.72 \\
(0.45)\end{array}$ & $\begin{array}{c}0.34 \\
(0.47)\end{array}$ & $\begin{array}{c}0.29 \\
(0.46)\end{array}$ & $\begin{array}{c}0.27 \\
(0.45)\end{array}$ & $\begin{array}{c}0.57 \\
(0.50)\end{array}$ \\
\hline \multirow{2}{*}{$\begin{array}{l}\text { Prison sentence } \\
\text { in years }\end{array}$} & 4.15 & 3.27 & 0.58 & 0.55 & 0.97 & 2.50 \\
\hline & $(3.22)$ & $(2.86)$ & (1.11) & $(1.16)$ & $(1.83)$ & $(2.96)$ \\
\hline \multirow{2}{*}{$\begin{array}{l}\text { Process duration } \\
\text { in years }\end{array}$} & 1.45 & 1.20 & 2.10 & 2.30 & 1.87 & 1.66 \\
\hline & $(1.48)$ & $(0.85)$ & $(1.83)$ & $(1.85)$ & $(1.46)$ & $(1.55)$ \\
\hline Observations & 22,244 & 16,278 & 15,167 & 7,331 & 3,702 & 64,722 \\
\hline \multicolumn{7}{|c|}{ Panel C. Mean variables: panel sample } \\
\hline \multirow[t]{2}{*}{ Employed $=1$} & 0.17 & 0.17 & 0.16 & 0.17 & 0.21 & 0.17 \\
\hline & $(0.37)$ & $(0.37)$ & $(0.36)$ & $(0.37)$ & $(0.41)$ & $(0.37)$ \\
\hline \multirow[t]{2}{*}{ Ever worked $=1$} & 0.55 & 0.53 & 0.51 & 0.54 & 0.60 & 0.54 \\
\hline & $(0.50)$ & $(0.50)$ & $(0.50)$ & $(0.50)$ & $(0.49)$ & $(0.50)$ \\
\hline Observations & 177,952 & 130,224 & 121,336 & 58,648 & 29,616 & 517,776 \\
\hline
\end{tabular}

Note: This table reports characteristics for Baseline sample of 64,722 cases judged in first instance by São Paulo Court of Justice between 2011 and 2017. Panel A brings the distribution of judicial sentence results across crime types studied. Sentences were issued from 2011 to 2017 and were publicly available in TJSP website. "Drug" refers to drug-related crimes; "firearm" are the related to irregular possession, commerce and carrying of guns and "stolen goods" refers to the crime of handling stolen goods. Panel B shows other information on observations of cross-sectional data given by the court. Finally, those criminal cases were merged with labour market records 2010-2017, RAIS, each observation of the cross-sectional were multiplied by 8 periods. Panel B brings information on the full panel created when following the working records of each defendant. Standard deviation in brackets. 
Table 3.2: Descriptive Statistics

\begin{tabular}{lccc}
\hline \hline & All & Convicted & Acquitted \\
\hline A. Court sample & & & \\
Prison sentence in years & 2.50 & 4.40 & 0.00 \\
& $(2.96)$ & $(2.66)$ & $(0.00)$ \\
Process duration in years & 1.66 & 1.28 & 2.16 \\
& $(1.55)$ & $(1.02)$ & $(1.93)$ \\
Observations & 64,722 & 36,796 & 27,926 \\
& & & \\
B. Panel sample & & & \\
Employed =1 & 0.17 & 0.16 & 0.18 \\
& $(0.37)$ & $(0.36)$ & $(0.38)$ \\
Ever worked =1 & 0.54 & 0.52 & 0.56 \\
& $(0.50)$ & $(0.50)$ & $(0.50)$ \\
Observations & 517,776 & 294,368 & 223,408 \\
& & & \\
C. Defendants found on labour market & \\
Schooling & 6.35 & 6.36 & 6.33 \\
& $(1.55)$ & $(1.54)$ & $(1.55)$ \\
Black = 1 & 0.38 & 0.39 & 0.37 \\
& $(0.49)$ & $(0.49)$ & $(0.48)$ \\
Age & 31.09 & 30.73 & 31.49 \\
Average wage $(\mathrm{R} \$)$ & $(10.38)$ & $(10.27)$ & $(10.50)$ \\
Observations & $1,555.95$ & $1,553.77$ & $1,558.48$ \\
& $(2,067.18)$ & $(1,956.45)$ & $(2,188.63)$ \\
& 83,831 & 45,020 & 38,811 \\
\hline
\end{tabular}

Note: This table reports mean characteristics for baseline sample of 64,722 cases judged in first instance by São Paulo Court of Justice between 2011 and 2017. Standard deviation in brackets. Panel A shows information on observations of cross-sectional data given by the court. Those criminal cases were merged with labour market records 2010-2017, RAIS, each observation of the cross-sectional were multiplied by 8 periods. Panel B brings information on the full panel created when following the working records of each defendant. Panel $\mathrm{C}$ shows statistics available in working records, for those who were eventually found working. 
Figure 3.1: Employment rate over time relative to trial

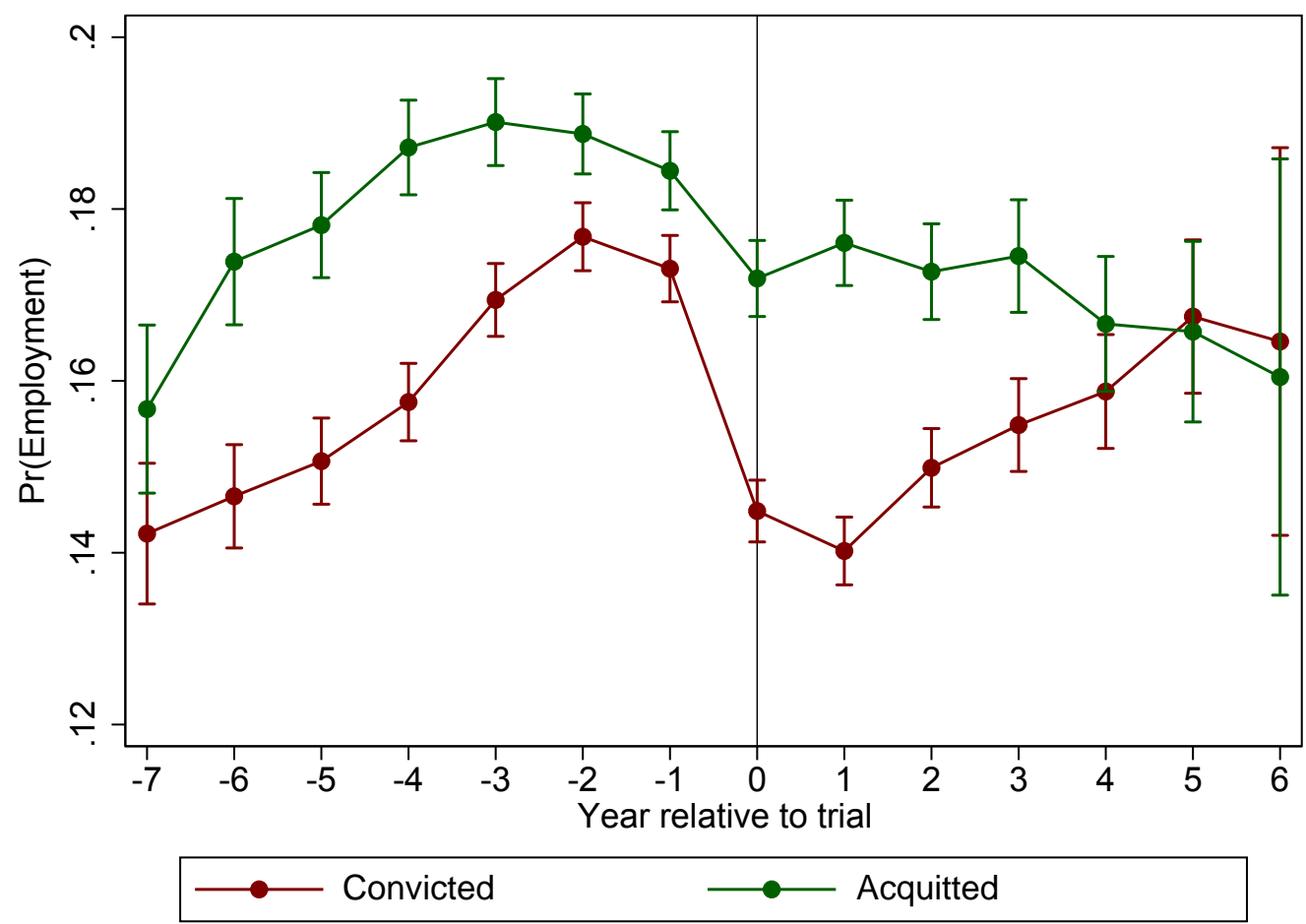

Note: Baseline sample mean of employment rate over time for defendants acquitted and convicted. The time of reference is the year of trial 


\section{4 \\ Research Design}

In order to understand if imprisonment affects the chances of being employed we must go beyond the simple comparison between convicted and acquitted, seeing that the difference in employability of these two groups might be correlated with non-observed socioeconomic and personal characteristics. One of our strategies to deal with this is using a fixed-effects regressing model, controlling for non-observed factors fixed in time.

In fact, we are interested in answering if ex-convicts are less likely to obtain formal employment. Therefore, there is a need to deal with the fact that our data does not inform us when convicts leave jail. ${ }^{1}$ We propose two ways of grasping this effect: i) study how the effect of being sentenced to prison behaves over time (in that way we might see it dissipating or reverting); or ii) study the effect of leaving prison, predicting the time in prison by time sentenced to prison. Hereafter, the first treatment studied is going to be called 'prison' and the second 'released'.

First, we propose a differences-in-differences approach to controls for nonobserved fixed effects and estimate the causal effect of both treatments.

\section{1}

\section{Prison Treatment}

For individual $i$ in year $t$, consider a model relating a labour market outcome, $Y_{i, t}$, to a dummy for his prison treatment status in period $t$, Prison $_{i, t}$. The prison status stays equal to one after the individual has been sentenced to prison.

$$
Y_{i, t}=\alpha_{0}+\sum_{\substack{r=-4 \\ r \neq-1}}^{r=5} \beta_{1, r} \text { Prison }_{i, t+r}+\sum_{\substack{r=-4 \\ r \neq-1}}^{r=5} \zeta_{1, r} J_{i, t+r}+\gamma_{t}+\theta_{i}+\epsilon_{i, t}
$$

This model is a difference-in-differences model, but in order to achieve parallel tendencies we also control for time fixed effects in referenced to the time of judgement. That role is performed by $J_{i, t}$, which is equal to one if the

\footnotetext{
${ }^{1}$ Our data only inform us if the defendant was convicted to prison and it's prison sentence
} time. There is no information on the actual time in prison. 
individual has ever being judged in $t$. The model also includes individual $\theta_{i}$ and time $\gamma_{t}$ fixed effects. Another way to visualise this equation is:

$$
Y_{i, t}=\alpha_{0}+\sum_{\substack{r=-4 \\ r \neq-1}}^{r=5} J_{i, t+r}\left(\zeta_{r}+\beta_{r} \text { convicted }_{i}\right)+\gamma_{t}+\theta_{i}+\epsilon_{i, t}
$$

where convicted $_{i}$ is an indicator variable equal to 1 if defendant $i$ has been sentenced to prison. The interaction between convicted $_{i}$ and judgement $J_{i, t}$ equals Prison $_{i, t}$. This means that we are investigating how the effect, over time, of being judged is distinct for those who were convicted from those who were not.

\section{2}

\section{Released Treatment}

When estimating the effect of being released from prison we use the following model

$$
Y_{i, t}=\alpha_{0}+\sum_{r=-6}^{r=3} \beta_{r} \text { Release }_{i, t+r}+\gamma_{t}+\theta_{i}+\epsilon_{i, t}
$$

where, for individual $i$ in year $t$, a labour market outcome $Y_{i, t}$, depends on Release $_{i, t}$, which is an indicator equal to one if the individual has ever being released from prison in $t$. Since we are not sure how much time each convicted spent in prison, we had to choose a proxy for it: the multiplication of time sentenced to prison by $1 / 3$ for those sentenced to closed regime, and $1 / 6$ for those to semi-open. These constants are arbitrary, but are based on time of penalty that must be served in order for the inmates to have the right to progress to the next regime, knowing that each progression to the next more beneficial regime can be done when convicts serve $1 / 6 .{ }^{2}$

\section{3}

\section{Instrumental Variable Approach}

The parallel trends assumption is required for the causal identification of difference in differences model: in the absence of treatment, the difference between the 'treatment' and 'control' group is constant over time. Therefore, the treatment parameters proposed in the last section might be biased. This would happen due to the simultaneous effect of some defendant's nonobservable time-varying characteristics (not captured by individual fixedeffect) on chances of being sentenced to prison and chances of getting a job. For example, those who suffered a negative income shock may have greater

\footnotetext{
${ }^{2}$ As explained in Section 2, beside the time served, good behaviour is required for the prisoner to progress to the next regime. Along with that, not every one entitled to the progression from the closed regime to semi-closed got a place there.
} 
chance of being sentenced to prison and smaller chance of getting a job in the future. If that is the case, we are going to be estimating a false negative effect of prison in employment.

One way to examine if the parallel trends assumption holds is to check if the lagged effects of prison treatment are equal to zero, making sure the causes do not come before the consequences. In order to make our analysis more robust we exploit a instrumental variable approach: the random assignment of judges and the heterogeneous incarceration tendencies of those judges. This leads to random variation in two outcomes, depending on which judge they are assigned to: i) the probability an individual will be incarcerated; and ii) prison sentence time. The first variation is used to draw inference about the causal effect of prison and both are used to infer about the effect of being released. It is worth noting that this econometric option identifies the local average treatment effect (LATE), the causal effect of judge decision for those in the margin of being acquitted.

To each defendant $i$ judged by judge $j(i)$ we define two instruments: incarceration propensity $(k=I P)$ and duration of prison time $(k=D P)$. The instruments are calculated as the leave-out mean:

$$
Z_{k, i}=\frac{1}{N_{j(i)}-1} \sum_{r=1}^{N_{j(i)}} x_{k, r}-x_{k, i}
$$

where $N_{j(i)}$ is the number of cases judged by judge $j, k \in\{I P, D P\}$, $x_{I P, r}$ is an indicator if sentenced to prison, and $x_{D P, r}$ is the amount of years sentenced to prison. Note that $x_{D P, r}$ is zero if $x_{I P, r}$ is equal to zero and greater than zero otherwise.

For our instrumental variable approach to identify the causal effect detention on employment, and in order to accurately predict the date of release, our instruments must be correlated to our endogenous variables. Figure 4.1 shows a histogram on the distribution of our instruments, presenting a visual description of the variation in judge tendencies, for both convicted and prison sentence time. The mean of incarceration propensity instrument is 0.56 which a standard deviation of 0.12 and the mean of prison sentence instrument is 2.5 with 0.50 of standard deviation. The histogram reveals a wide spread in a judge's tendency to incarcerate, since a judge at the 90th percentile incarcerates about $70 \%$ of cases as compared to approximately $43 \%$ for a judge at the 10th percentile. 
Figure 4.1: Histogram of instruments
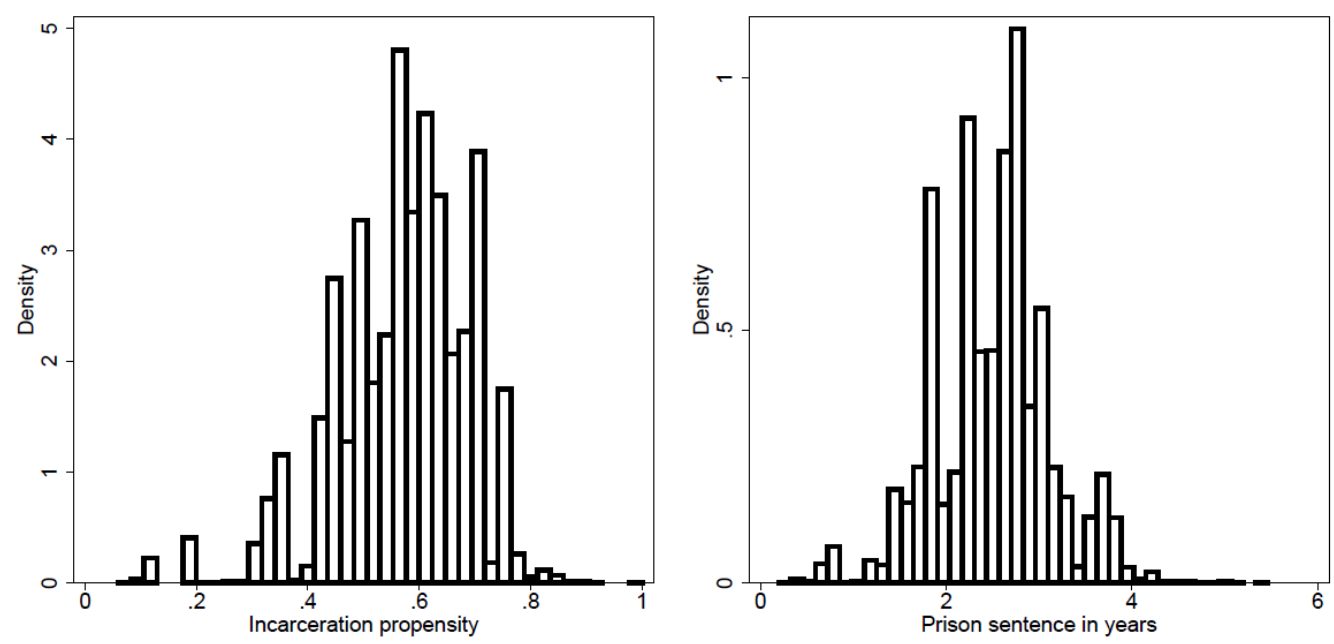

Note: Histogram on the density of instruments used in the regressions, for both incarceration and prison sentences

\section{4}

\section{First Stage}

After each of the two instruments are calculated we proceed estimating the first stage. For each lead and lag of the prison treatment $P_{i, h}$, we run

$$
\operatorname{Prison}_{i, t}=\delta_{0}+\sum_{\substack{r=-4 \\ r \neq-1}}^{r=5} J_{i, t+r}\left(\lambda_{1, r}+\lambda_{2, r} \cdot Z_{I P, i}\right)+\gamma_{t}+\theta_{i}+\mu_{i, t}
$$

where $Z_{I P, i}$ is the incarceration propensity, $J_{i, t}$ is an indicator equal to one if the individual has ever been judged in $t$ and Prison $_{i, h}$, the outcome of interest.

The first stage for released treatment is

$$
\text { Release }_{i, t}=\delta_{0}+\sum_{\substack{r=-4 \\ r \neq-1}}^{r=5} J_{i, t+r}\left(\lambda_{1, r}+\lambda_{2, r} Z_{I P, i}+\lambda_{3, r} Z_{D P, i}\right)+\gamma_{t}+\theta_{i}+\mu_{i, t}
$$

which is similar from prison treatment, only adding the duration of prison time defendant instrument.

Table 4.1 presents first stage estimates, where only coefficients statistically different from zero with $95 \%$ confidence level are reported. Columns 1 and 2 include estimation of prison and release effects, based on equations 4-5 and 4-6, respectively. Both regressions include individual fixed-effects and time effects. Column 1 shows that, as expected, the incarceration propensity mea- 
sure multiplied by current judgement dummy is a good predictor of prison. Column 2 shows that present judgement dummy together with some of its leads, interacted or not with both instruments, predicts the release treatment. Columns 3 and 4 present a pseudo first stage, exhibiting the simple correlation of our endogenous variables with each instrument proposed. Column 3 suggests that being assigned to a judge with a 10 p.p. higher incarceration propensity increases the probability of receiving a prison sentence by 9.5 percentage points. For example, if someone who was judged by 25 th percentile more rigorous judge had been judged by 75 th percentile judge (incarceration propensities equal $50 \%$ and $64.7 \%$, respectively), his

her would have been increased in 14 p.p. It worth noticing that in the 4 columns, the F-test fails to reject the exclusion of instruments hypothesis. Appendix D exhibit the same table but for the subsamples of crime types.

\section{5}

\section{Instrument Validity}

There are two sufficient assumptions under which the 2SLS identifies the local average treatment effect: i) the allocation of a judge correlates with the defendants future results only through the severity of the prison sentence (exogeneity); and ii) the likelihood of receiving a prison sentence is monotonically increasing in the judge stringency instrument (monotonicity) (Angrist et al., 1996).

One necessary, but not sufficient, condition to exogeneity is that the instrument must be uncorrelated with both defendant and case characteristics that could affect a defendant's future outcomes. In order to verify this condition we fist perform a test: we check if there is a significant correlation between the instruments and some observable characteristics before trial. Under exogeneity there should be no correlation.

Table 4.2 presents the resulting estimations of simple linear regression between some characteristics and each instrument. The observations selected for each regression are just those before trial. This table suggests that judges are randomly assigned to cases, since there is negligible correlation between instruments and each variable available. Table B.1 shows the same outcome by each crime type separately. Another possible test to check exogeneity of incarceration propensity instrument is to check if our proposed differences-indifferences instrumental variable (DD-IV) results hold parallel pre-trends.

Besides that, if we want to interpret DD and DD-IV instrumental variable results as causal, sentence to prison and judges incarceration propensity, respectively, can only affect defendant's outcomes through the incarceration 
Table 4.1: First stage results

\begin{tabular}{|c|c|c|c|c|}
\hline & $\begin{array}{c}(1) \\
\text { Prison }_{t 0}\end{array}$ & $\begin{array}{c}(2) \\
\text { Release }_{t 0}\end{array}$ & $\begin{array}{c}(3) \\
\text { convicted=1 }\end{array}$ & $\begin{array}{c}(4) \\
\text { prison sentence }\end{array}$ \\
\hline$Z_{I P}$ & & & $\begin{array}{c}0.953^{* * *} \\
(0.016)\end{array}$ & \\
\hline$Z_{P S}$ & & & & $\begin{array}{c}0.933^{* * *} \\
(0.019)\end{array}$ \\
\hline$J_{t 0}$ & $\begin{array}{c}0.027^{* * *} \\
(0.006)\end{array}$ & $\begin{array}{l}0.020^{* *} \\
(0.007)\end{array}$ & & \\
\hline$J_{t+1}$ & $\begin{array}{l}-0.002 \\
(0.007)\end{array}$ & $\begin{array}{c}0.051^{* * *} \\
(0.007)\end{array}$ & & \\
\hline$J_{t+2}$ & $\begin{array}{c}0.004 \\
(0.007)\end{array}$ & $\begin{array}{c}-0.034^{* * *} \\
(0.008)\end{array}$ & & \\
\hline$Z_{I P} \cdot J_{t 0}$ & $\begin{array}{c}0.956^{* * *} \\
(0.009)\end{array}$ & $\begin{array}{c}0.388^{* * *} \\
(0.025)\end{array}$ & & \\
\hline$Z_{I P} \cdot J_{t+1}$ & $\begin{array}{c}0.007 \\
(0.011)\end{array}$ & $\begin{array}{c}0.644^{* * *} \\
(0.026)\end{array}$ & & \\
\hline$Z_{I P} \cdot J_{t+2}$ & $\begin{array}{l}-0.003 \\
(0.013)\end{array}$ & $\begin{array}{c}0.203^{* * *} \\
(0.030)\end{array}$ & & \\
\hline$Z_{I P} \cdot J_{t+3}$ & $\begin{array}{l}-0.009 \\
(0.015)\end{array}$ & $\begin{array}{c}-0.201^{* * *} \\
(0.036)\end{array}$ & & \\
\hline$Z_{P S} \cdot J_{t 0}$ & & $\begin{array}{c}-0.058^{* * *} \\
(0.005)\end{array}$ & & \\
\hline$Z_{P S} \cdot J_{t+1}$ & & $\begin{array}{c}-0.081^{* * *} \\
(0.005)\end{array}$ & & \\
\hline$Z_{P S} \cdot J_{t+2}$ & & $\begin{array}{c}0.047^{* * *} \\
(0.006)\end{array}$ & & \\
\hline$Z_{P S} \cdot J_{t+3}$ & & $\begin{array}{c}0.067^{* * *} \\
(0.007)\end{array}$ & & \\
\hline Observations & 517,776 & 517,776 & 64,722 & 64,722 \\
\hline Defendants & 64,722 & 64,722 & & \\
\hline F-statistic & 26,181 & 9,049 & 3,487 & 2,542 \\
\hline $\mathrm{R}^{2}$ & 0.591 & 0.425 & 0.052 & 0.038 \\
\hline $\mathrm{R}^{2}$ within & 0.591 & 0.425 & & \\
\hline $\mathrm{R}^{2}$ between & 0.268 & 0.319 & & \\
\hline $\mathrm{R}^{2}$ overall & 0.461 & 0.386 & & \\
\hline $\begin{array}{l}\text { F-test exclusion } \\
\text { of instruments }\end{array}$ & 0.000 & 0.000 & 0.000 & 0.000 \\
\hline
\end{tabular}

Note: Columns 1 and 2 present baseline sample estimates from first stage model presented in equation 4-5 for prison and equation 4-6 for release treatment. Regressions include individual fixed-effects and time fixed effects. Only coefficients statistically different from zero, with $95 \%$ confidence, are reported. Columns 3 and 4 present a pseudo first stage, showing the correlation between endogenous variable and instrument.

Standard errors in parentheses, ${ }^{*} \mathrm{p}<0.05,{ }^{* *} \mathrm{p}<0.01,{ }^{* * *} \mathrm{p}<0.001$ 
sentencing channel. Any other factor depending on judge's practice that might affect defendant's chance to get a job in the future, such as enforcement of fines and duration of prosecution phase must be considered. We employed a robustness test, checking if the estimated effects change when we control for process duration interacted with time fixed effects. No significant change was found. ${ }^{3}$

In presence of heterogeneous effects of incarceration, we should also be concerned with monotonicity assumption. Under monotonicity assumption individuals whose detention was ordered by a strict (lenient) judge would also have been convicted (acquitted) by a stricter (more lenient) judge.

There are two testable implications of monotonicity: i) first stage estimates are non-negative for any subsample; ii) out of subsample stringency must be a predictor for judge stringency in the sample, for any subsample. Our dataset let us test these implications for different crime types and for defendants subsamples of individuals with less or more common names. First stage results of the first test are in Appendix D, and first stage estimates are always positive. To test the second implication, we redefine the instrument for each subsample to be the judge's incarceration rate for cases outside of the subsample. Appendix C Table C.1 lists the first stage estimates using the new instruments. First stage estimates are all positive and statistically different from zero, suggesting that judges who are stricter for one type of case are also stricter for other case types.

\footnotetext{
${ }^{3}$ We do not have access to data on fines to further deal with this issue.
} 
Table 4.2: Correlation between instruments and pre-trial characteristics

\begin{tabular}{|c|c|c|c|c|c|}
\hline \multirow[b]{2}{*}{ Dependent variable } & \multirow[b]{2}{*}{$\begin{array}{c}(1) \\
\text { Coefficient } \\
\text { estimate }\end{array}$} & \multirow[b]{2}{*}{$\begin{array}{l}(2) \\
\text { Standard } \\
\text { error }\end{array}$} & \multirow[b]{2}{*}{$\begin{array}{c}(3) \\
\text { P-value }\end{array}$} & \multicolumn{2}{|c|}{ Dependent variable } \\
\hline & & & & $\begin{array}{c}(4) \\
\text { Mean }\end{array}$ & $\begin{array}{c}(5) \\
\text { Standard } \\
\text { deviation }\end{array}$ \\
\hline \multicolumn{6}{|c|}{ A. Independent variable: incarceration propensity } \\
\hline $\begin{array}{l}\text { Employed = } 1 \\
\text { Observations }\end{array}$ & $\begin{array}{c}0.005 \\
295,573\end{array}$ & 0.006 & 0.451 & 0.17 & 0.38 \\
\hline Schooling & 0.063 & 0.059 & 0.285 & 6.24 & 1.55 \\
\hline Black $=1$ & $-0.039^{*}$ & 0.018 & 0.034 & 0.38 & 0.48 \\
\hline $\begin{array}{l}\text { Age } \\
\text { Observations }\end{array}$ & $\begin{array}{l}-0.333 \\
51,187\end{array}$ & 0.387 & 0.389 & 29.86 & 10.20 \\
\hline $\begin{array}{l}\text { Wage }(\mathrm{R} \$) \\
\text { Observations }\end{array}$ & $\begin{array}{c}-64.160 \\
49,330\end{array}$ & 77.904 & 0.410 & $1,476.88$ & $2,018.92$ \\
\hline \multicolumn{6}{|c|}{ B. Independent variable: prison sentence } \\
\hline $\begin{array}{l}\text { Employed }=1 \\
\text { Observations }\end{array}$ & $\begin{array}{c}-0.001 \\
295,573\end{array}$ & 0.001 & 0.353 & 0.17 & 0.38 \\
\hline $\begin{array}{l}\text { Schooling } \\
\text { Black }=1 \\
\text { Age } \\
\quad \text { Observations }\end{array}$ & $\begin{array}{l}0.021 \\
-0.005 \\
-0.028 \\
51,187\end{array}$ & $\begin{array}{l}0.011 \\
0.003 \\
0.073\end{array}$ & $\begin{array}{l}0.056 \\
0.178 \\
0.699\end{array}$ & $\begin{array}{c}6.24 \\
0.38 \\
29.86\end{array}$ & $\begin{array}{c}1.55 \\
0.48 \\
10.20\end{array}$ \\
\hline $\begin{array}{l}\text { Wage }(\mathrm{R} \$) \\
\text { Observations }\end{array}$ & $\begin{array}{l}-22.59 \\
49,330\end{array}$ & 14.617 & 0.122 & $1,476.88$ & $2,018.92$ \\
\hline
\end{tabular}

Note: Correlation between the instruments and defendants characteristics, only available in RAIS, were evaluated before the trial. The number of observations vary depending on the dependent variable pretrial availability. 


\section{5 \\ Results}

In this section, we present the results for the estimated effects of prison and release treatment on employment, following the differences-in-differences (DD) and differences-in-differences instrumental variable (DD-IV) strategy described in section 4 . First we estimate the overall effect of prison and release treatment on probability of being employed. We, then, investigate effects' heterogeneities based on crime types and prior employment. Finally we see how the results behave when we estimate the effect for the subsample of defendants with less common names.

\section{1}

\section{Main results}

Figure 5.1 graphically presents DD estimates of the effect of incarceration on the probability of employment. Incarceration happens exactly when defendant is sentenced to prison and employment reflect the formal job hiring. The graph shows both leads and lags coefficients as proposed in equation 4-1, showing point estimates and 95\% confidence interval. The effects are moderate, and the point estimates range from 0.015 to -0.016 . In the year of judgement, being sentenced to prison decreases the probability of being employed in 1,6 percentage points (p.p.) ( the confidence interval of 95\% confidence level rages from 2,1 to 1 p.p.). The coefficients on prison treatment after two years of prison treatment show positive effects of prison on employment. Since the coefficient in period two is 0.013 we say that two years after trial, being sentenced to prison increases in 1,3 p.p. (CI: $0,5-2,1)$ the probability of employment compared to those acquitted.

The results for release effects show some small correlation between being released from prison and employment. The effect is still quite small, but compared with the negative effect of being sentenced to prison (both visible in the prison and release treatment graphs) it becomes relevant.

The parallel trends assumption does not seem to hold in this first estimation. The effects of being sentenced to prison precede the consequences as the lag coefficients are statistically different from zero. However, these effects are in the opposite direction to our prior, which was: those who suffered from 
Figure 5.1: Overall DD results

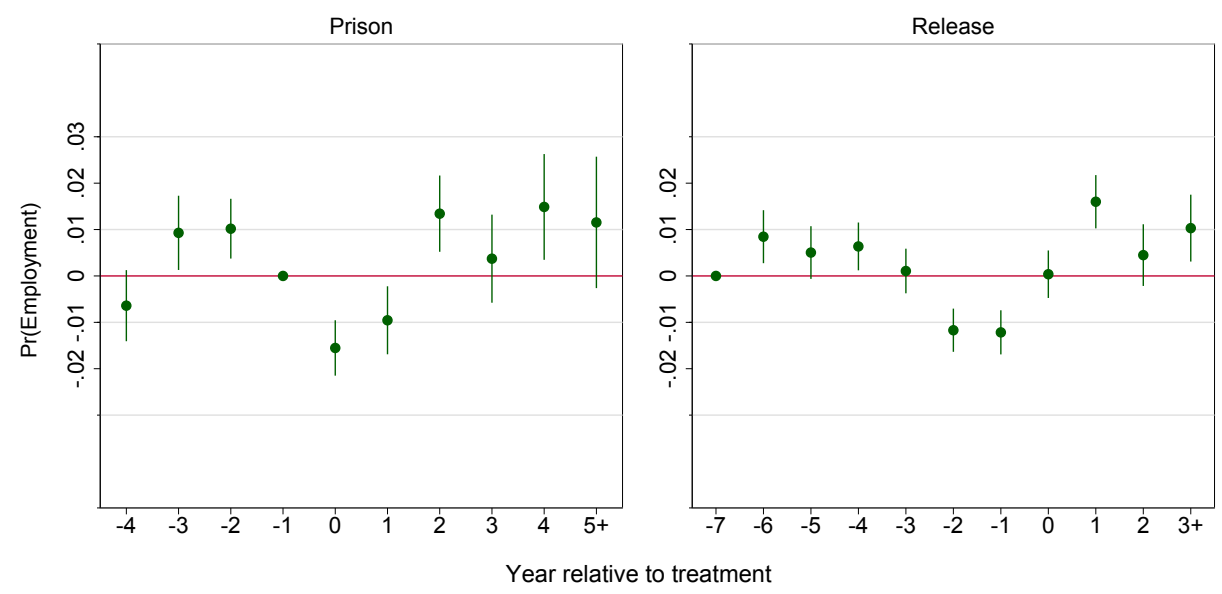

a negative shock in employment decided to commit crimes. However, it might be the case that convicted and acquitted do not differ in having committed a crime or not, but they are split into these two groups by trial based on previous crime history. Some of this effect might be coming from the fact that those acquitted, including those sentenced to small penalties such as house arrest, education programs and social work, are not recidivist. Beginners in crime are the ones who had suffered a negative shock in employment and had been acquitted. This trend is clear in Figure 5.2, where it is shown point estimates and $95 \%$ confidence interval on the DD estimation on the effect of judgement effect over time for two distinct subsamples: acquitted and convicted. There, those acquitted seem to have suffered a negative shock in employment prior to trial.

Figure 5.2: DD differences in judgement effect.

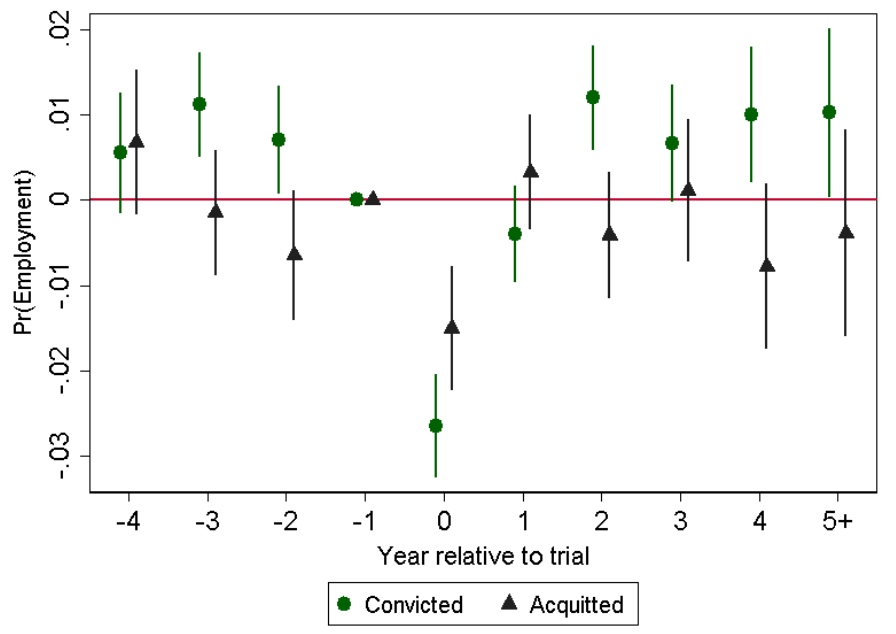


Figure 5.3: Overall DD results - crime types $\times$ time fixed effects

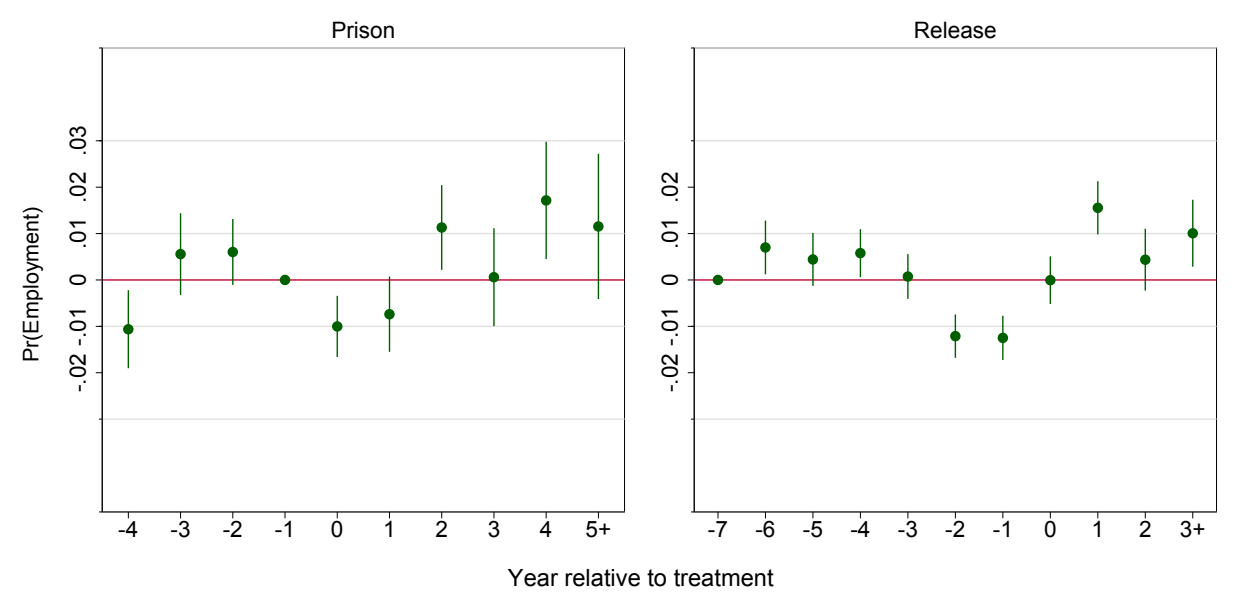

If we choose to control for interactions between crime types and time fixed effects, these anticipatory effects diminish. They actually became negative in four years or less prior to treatment. As we can seen in Figure 5.3, point estimates are almost all the same and we may conclude that it is not the difference in time fixed effects across crime types that are driving our positive results.

Another proposal to deal with the lack of parallel trends is the use of instrumental variable approach, using judge stringency as a instrument for being sentenced to prison. Figure 5.4 presents these estimates for two treatments proposed, showing significant results only for the year of prison treatment. The effects are rather noisy and the lack of precision allow us to grasp only obvious incapacitating effects, reduction in employment due to time in jail. We can conclude that the instrumental variable approach also suggests a reversion of the immediate negative effect, but with no statistically significant positive effect.

Ideally, due to the lack of parallel trends, we would rely on DD-IV method to draw our conclusions on the result, but the moderate effects together with increased standard error only allow us to say that if there is any effect of prison on future employment it was not detected. The results based on DD method present smaller standard error, but we can not take them as causal. We may overcome this impediments on the search for a conclusion interpreting the DD results as suggestive. Therefore we say that the negative effects of prison on employment seem to diminish over time. 
Figure 5.4: Overall DD-IV results

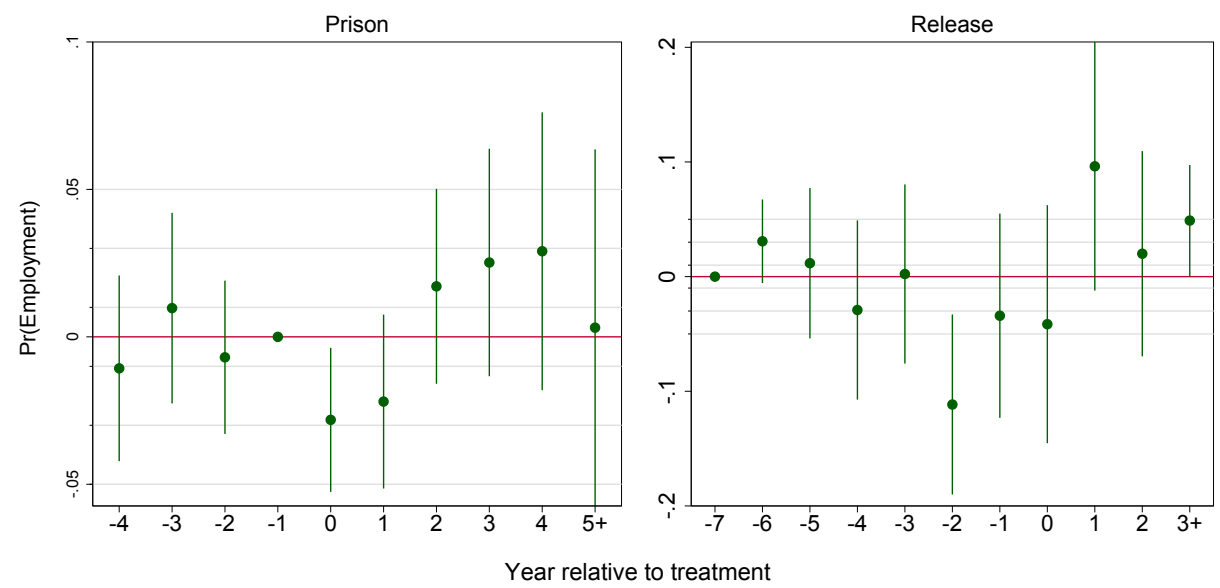

\section{2}

\section{Heterogeneity of the effect among crime types}

One way to check if these results are robust is to see how heterogeneous they are across crime types, going beyond the simple control for interactions between crime types and time fixed effects. Besides that, when studying the heterogeneous effect we would like to find if the parallel assumption holds for some of the groups.

First, in Figure 5.5, we look to the DD effects for those judged by the crime of robbery, acknowledging that the results are not that different from the baseline sample, only being less precise and with greater anticipatory effect. Besides that, the positive effects that shows after three years of treatment are significant in a $90 \%$ confidence level. Point estimates show that in the third and fourth year relative to trial the probability of getting a job are 2 p.p. greater for those convicted. Release effect points to the same direction but with reduced size. One year after being released the chances of being employed is about 1 p.p. greater.

In 5.6 we see the DD results for drug-related crimes. Despite the lack of positive effect in the lagged coefficients, the positive effects after two years are still there. The positive, still moderate, effects are present one year after the release treatment. As before, their point estimates suggest that this positive effect reduce over time.

Similarly, Figure 5.7 shows the effect for those defendants prosecuted using the differences-in-differences method specified in equations 4-1 and 4-3, but this time for the crime of theft. Even though the results are mostly noisy, we can still see positive results two years after prison treatment and one year after release treatment. These are not statistically significant, but it's p-values 
Figure 5.5: Robbery DD results

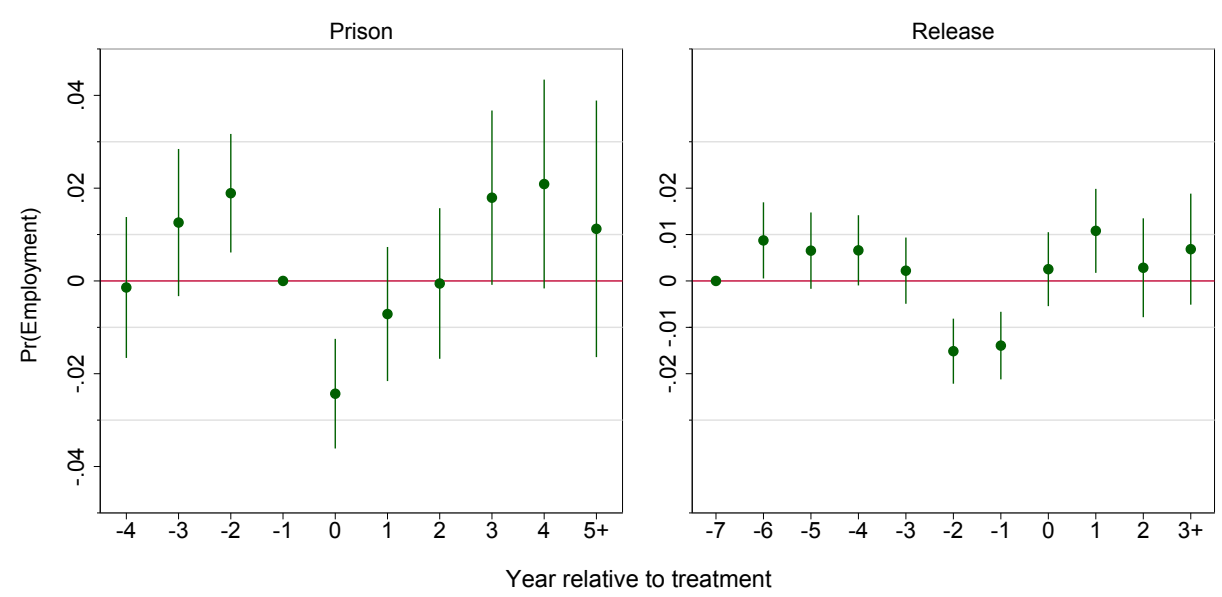

Figure 5.6: Drug-related DD results

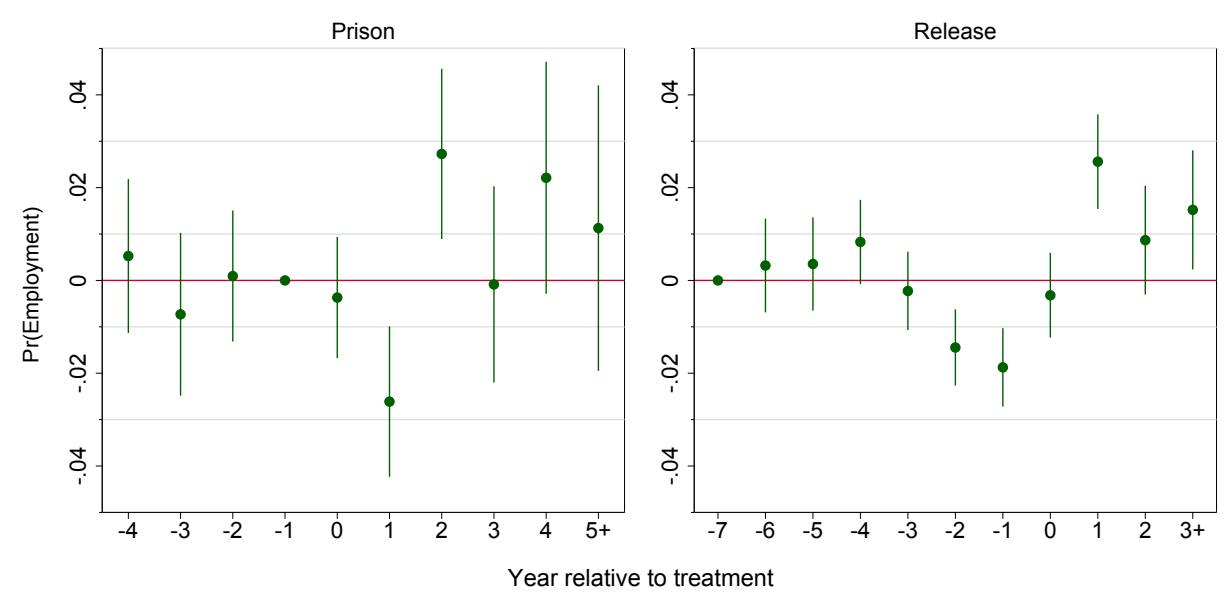

are 0.06 and 0.07 , respectively. It calls attention the lack of negative effects during the year of adoption. It might be the case that prison for a minor crime as theft is not sufficiently enforced.

Effects for those defendants accused of handling of stolen goods and possession of firearm are mostly noisy for DD and DD-IV estimates. This may be because the lack of observations and again by the measurement error in our dependent variable. DD estimates are presented in Appendix E Figures E.1 and E.2; and DD-IV estimates are in Appendix E Figures E.3 and E.4. There are some estimates statistically different from zero, but since there is no noticeable trend and since we are dealing with many estimates, there must be extra parsimony in interpreting results as different from zero.

Parallel trends still is an issue, specially for those defendants involved in 
Figure 5.7: Theft DD results

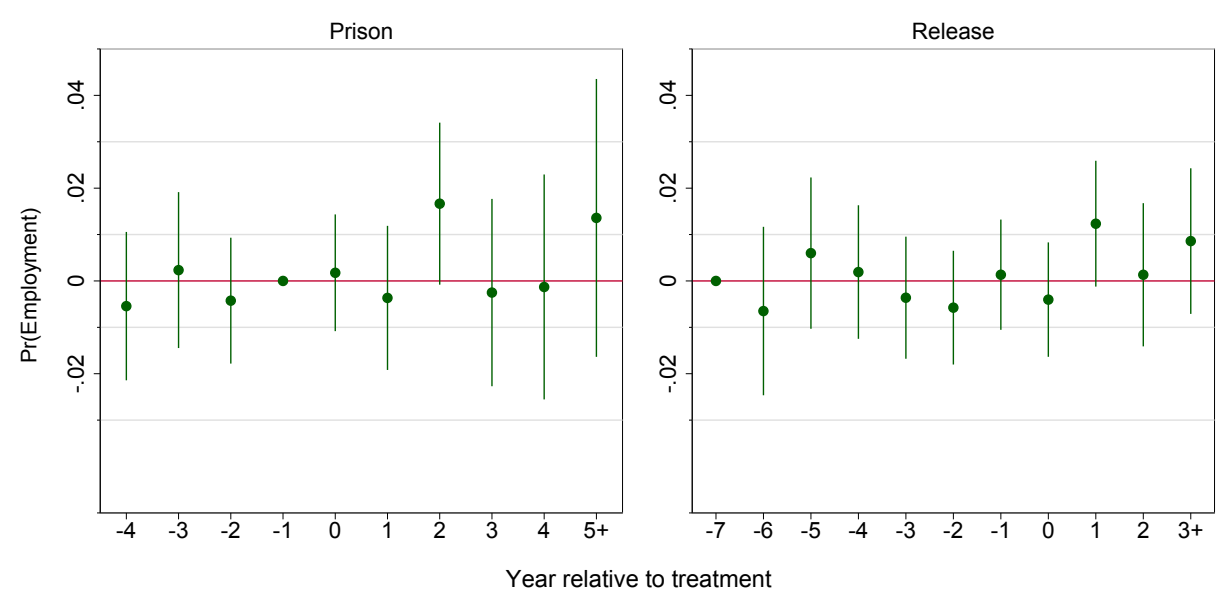

robbery. In order to solve this problem and check the robustness of our effects, following we show the DD-IV estimates for robbery, drug-related and theft crimes.

Figure 5.8 presents coefficients for robbery showing again that these are quite similar to overall results. The only coefficient of prison treatment different from zero is the negative one corresponding to the effects on the year of treatment. Again it shows no statistically significant positive effect on release.

Figure 5.8: Robbery DD-IV results

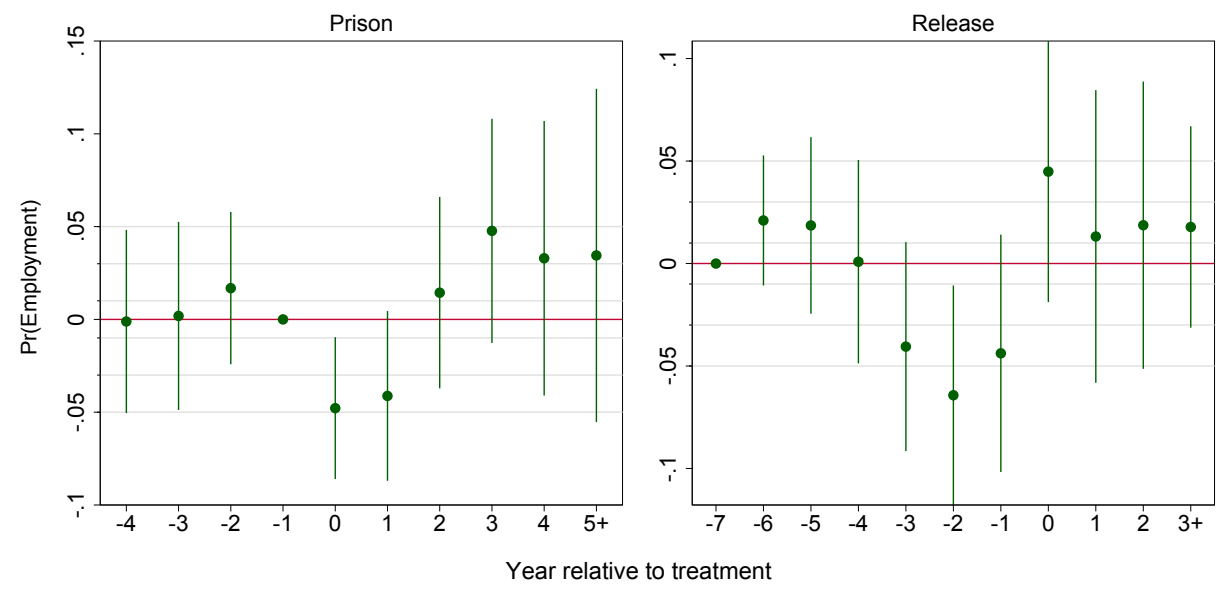

Figure 5.9 shows the effect for drug-related crimes. The general trend of point estimates for prison treatment are the same of robbery. Negative effects on the year of adoption lasting only until one year after; and no effects 
or slightly positive from the second year onward. Release effect support this results.

Figure 5.9: Drug-related DD-IV results

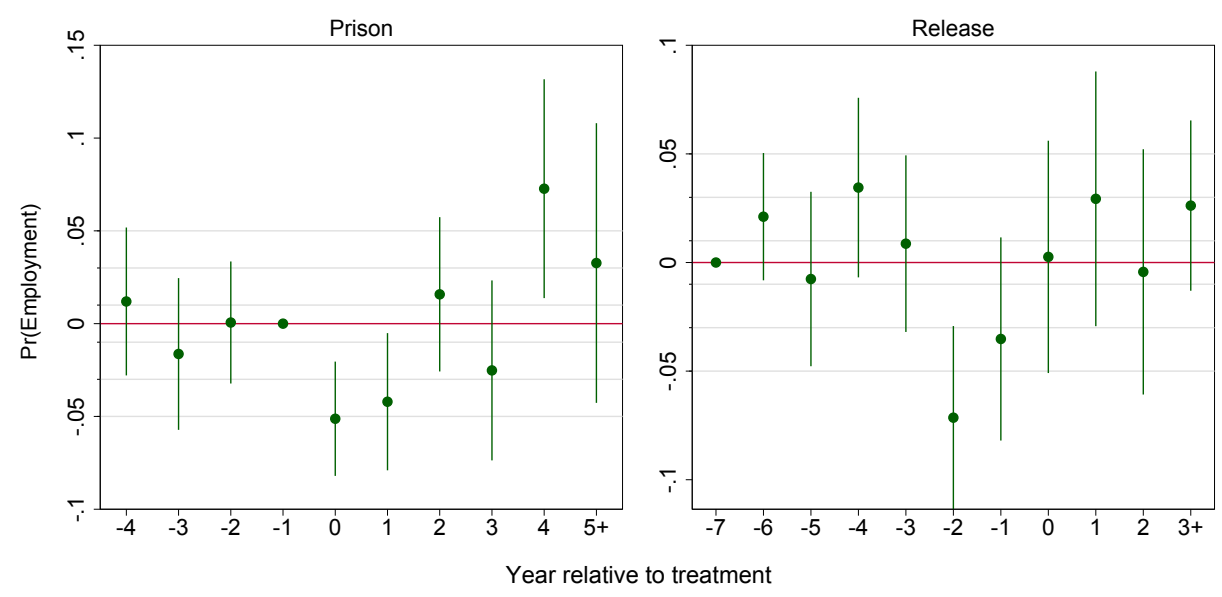

The results, showed in Figure 5.10, for DD-IV model regarding theft crimes are rather hard to interpret. The lack of parallel trend regarding the use of instrumental variable is alarming, however these coefficients certainly do not contradict our results.

In the end we may conclude that our results are robust to the division into subsamples of crime type. The overall results, presented in the last section, seem to be driven by robbery and drug-related crimes. These crimes account for roughly $60 \%$ of our sample. It calls attention the fact that not even DD method, that is more precise, detected the probable short-term negative effect of prison treatment for theft.

\section{3}

\section{Robustness check: restrict to less frequent names}

Full names were the only identifiers in the court database that we use to search for the defendant in the formal labour market database, RAIS. Therefore, sometimes defendants that were supposedly not working were found working, and others were matched the wrong worker. This form of measurement error, when one individual is not working and it is find working, is expected to underestimate the explanatory power of the independent variable and increase standard error. In order to deal with this issue we propose to look closely to the effects upon those defendants with less common names.

That group was constructed in the following manner. First, when merging the two databases we counted how many distinct workers where merged with 
Figure 5.10: Theft DD-IV results

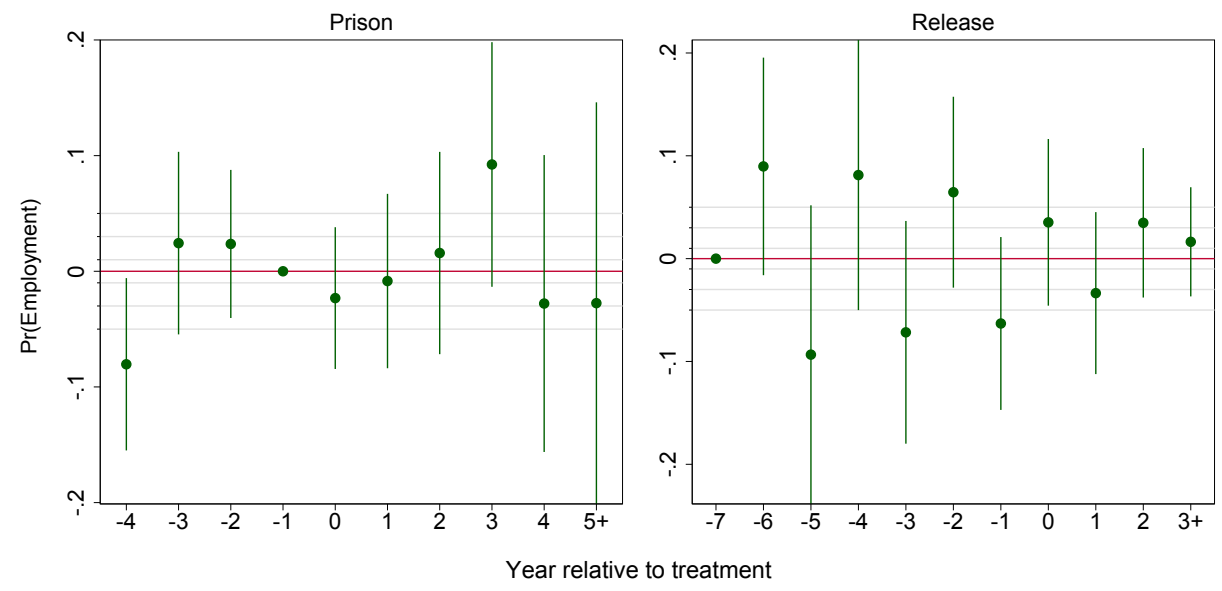

certain defendant. We considered defendants with less frequent name if they were combined with at most one worker. Out of 64,722 defendants, 45,663 were selected to this group. The proportion of acquitted/convicted is the same for this subsample and the baseline sample. However the employment rate dropped from $16,7 \%$ to $10,3 \%$

Figure 5.11 presents results of DD model for the described subsample. The estimates are almost equal to baseline ones, and again the lack of parallel trends poses a problem to causal interpretation of the results. In Figure 5.12 we show the effect for DD-IV approach. This time, different from results with baseline sample, a positive effect emerged on the 4th year. Yet, overall effects are quite similar to our main results, but are greater if compared to mean variable.

Figure 5.11: Less common name - DD results

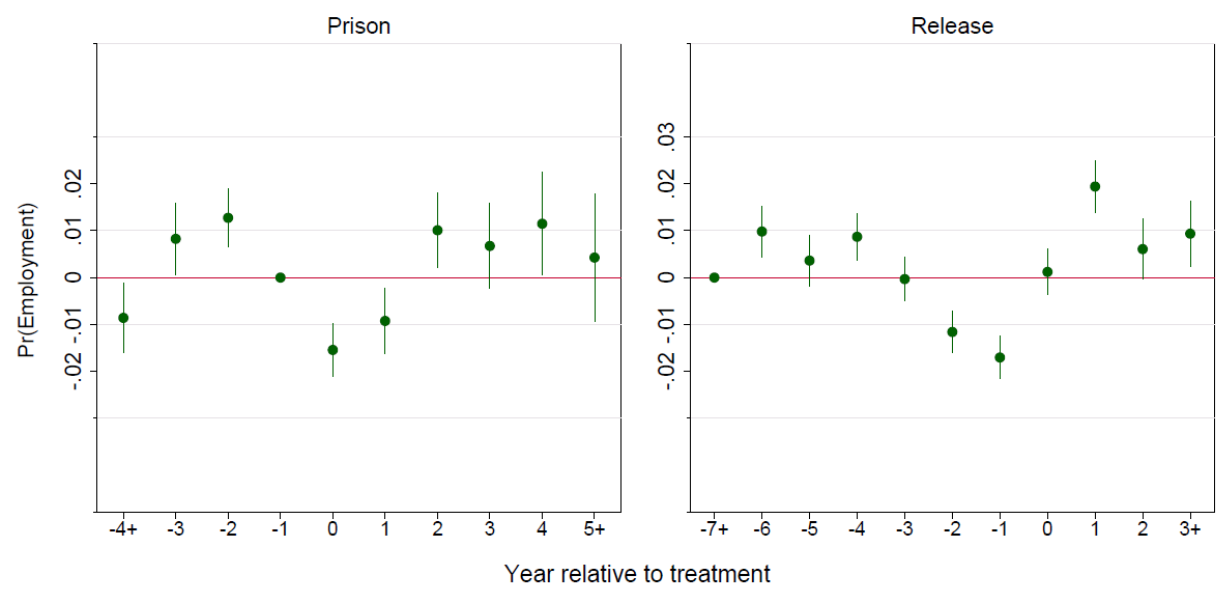


Figure 5.12: Less common name DD-IV results

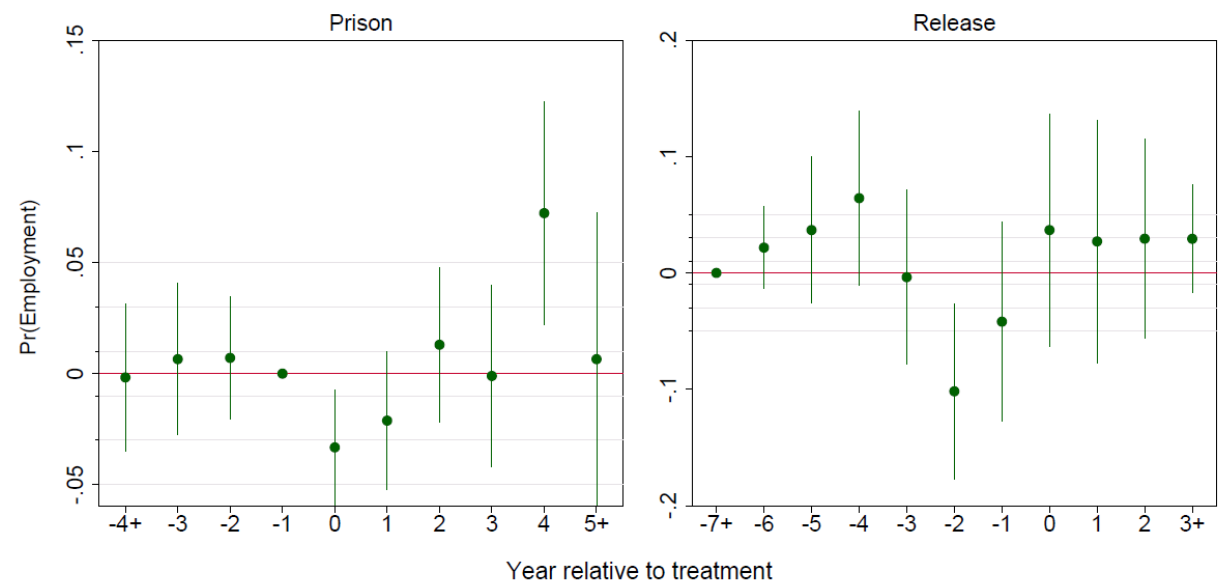




\section{6 \\ Conclusions}

This paper examines the effects of incarceration on future employment. We address this question in the context of justice system of Brazil, in particular São Paulo City. We construct a novel panel dataset merging defendants with their formal labour market record. Essentially, we compare the employment of two groups: those sentenced to prison and those who were not sentenced.

First, we explore defendant and time fixed effect, analysing how being sentenced affects the individual dynamics of employment. In this setting, we presented how the effect of being convicted differs from those acquitted in respect to the time of judgement. To make sure our results are not being driven by differences in tendencies prior to trial between those to groups, we also implement a instrumental variable approach, exploiting the random assignment of criminal cases to judges, who differ systematically in their stringency in sentencing defendants to prison.

The difference-in-differences method approach resulted in a instant negative effect of prison, followed by a reversion in the signal of it, suggesting a slightly positive effect of prison on employment three years after trial. Nevertheless, parallel trends assumption does not seem to hold. The instrumental variable approach permitted identify the same immediate negative effect, but the increase in standard error have not allowed to reject the hypothesis of zero effect after the second year.

The point estimates for the effect of prison treatment in the year of adoption ranges from 1.5 to 3 percentage points. This effect happens probably due to the lack of formal work available for the inmates. However, these negative effects are smaller than we would expect, especially if compared to the mean of dependent variable, which is $17 \%$. The presence of homonyms and the use of name as defendants identification on formal labour database resulted in measurement error in the dependent variable. Probably, employment rate among the defendants were not as high as $17 \%$. Besides that, we are not certain that every one who was sentenced to prison actually was imprisoned.

Ideally, we would like to have relied solemnly on the DD-IV method to drive such conclusions, but the method have not allowed us, since emerged sizeable standard errors and small effects. However, if we consider differences- 
in-differences results as suggestive, we can say our results go against previous findings on the literature, specially the ones deducted from closer institutional context. In the DD context, two years after treatment some positive effects were found, specially when relying on found two years or after. The positive effects are not substantial, and do not seem persistent, but it is still surprising, since our prior was that being sentenced to prison had a detrimental effect on future employment. When considering DD results as suggestive, we may be extra cautious to interpret a reversion of the effect, but we can say it indicates that the negative effect diminish over time.

These effects, of first negative shock on employment followed by reversion to zero in maximum of three year, are is fairly robust. We explored heterogeneity in effects according crime type and found that our results were mostly driven by robbery and drug-related crimes. We find no consistency on statistically significant effects for defendants accused of theft, handling of stolen goods and firearm possession.

Our results are not tightly in line with recent and more sophisticated research on the effect of incarceration on employment. Since Kling (2006), some have used the random assignment of judges to draw conclusions on the matter and on recidivism. There are studies showing results in both directions and also inconclusive ones. Dobbie et al. (2018) and Mueller-Smith (2015) report negative effect of prison on wages and employment while Aizer and Jr. (2015) found that juvenile prison reduces educational attainment. Diversely, but also using data from USA, Kling (2006) detected positive impact of prison length on labour market outcomes. Combined with it, but in the context of Norway's criminal justice system, Bhuller et al. (2016) also encountered positive effect of prison on labour market outcomes, specially for those who have not work before.

The lack of consensus might emerge because incarceration effects could vary depending on a prisoner's background or prison conditions. Our finding conflicts with the published study built upon social conditions closer to Brazil, Di Tella and Schargrodsky (2013). They study the effect of electronic monitoring in comparison to prison and find negative effects on recidivism, which translates into criminogenic impact of prison if compared with lighter penalties.

The discrepancy may be related to the fact that they work with pre-trial detainees in Buenos Aires, not São Paulo. As we showed in Section 2, prison conditions in São Paulo are far from ideal, but there are programs intended to help ex-inmates to exercise citizenship and find jobs. Besides that, generally companies in Brazil are not allowed to require police records for a job vacancies 
which might reduce stigmatisation.

The lack of more research on developing countries only confirms the demand for further research. Specially one able to evaluate future employment over a longer period of time and also able to disentangle the mechanism responsible for the effects. Provided with information on the underlying mechanisms policy makers will be able to better decide on the circumstances at which prison is effective. 


\section{7}

\section{Bibliography}

Adorno, S. and Bordini, E. (1989). Reincidencia e reincidentes penitenciarios em sao paulo: 1974-1985. Revista Brasileira de Ciencias Sociais.

Aizer, A. and Jr., J. J. D. (2015). Juvenile incarceration, human capital, and future crime: Evidence from randomly assigned judges. The Quarterly Journal of Economics, 130(2):759-803.

Angrist, J. D., Imbens, G. W., and Rubin, D. B. (1996). Identification of causal effects using instrumental variables. Journal of the American Statistical Association, 91(434):444-455.

Arcoverde, L. (2016). 8.870 presos esperam vaga no semiaberto em são paulo. Fiquem Sabendo.

Barros, R. A. L. d. (2016). Uma leitura de Golden Gulag: rediscutindo a economia política da pena e uma aproximação com o debate sobre a expansão prisional no estado de São Paulo. Sociedade e Estado, 31:799 - 819.

Bergman, M., de Jesus Filho, J., Fondevila, G., and (coord.), C. V. (2013). Crime, segurança pública e desempenho institucional em são paulo. relatório sobre as unidades prisionais em são paulo, brasil perfis gerais, contexto familiar, crimes, circunstâncias do processo penal e condições de vida na prisão. Technical report.

Bhuller, M., Dahl, G. B., Løken, K. V., and Mogstad, M. (2016). Incarceration, recidivism and employment. Working Paper 22648, National Bureau of Economic Research.

Biondi, K. et al. (2009). Junto e misturado: imanência e transcendência no pcc.

Brasil (1940). Código penal. decreto-lei $\mathrm{n}^{\circ} 2.848$, de 7 de dezembro de 1940 .

Brasil (1999). Tribunal de justiça do estado de são paulo (tjsp). corregedoria geral de justiça do estado de são paulo. provimento 38/1999.

Brasil (2014). Novo diagnóstico de pessoas presas no brasil. Technical report, Ministério da Justiça e Segurança Pública, Conselho Nacional de Justiça, 
Departamento de Monitoramento e Fiscalização do Sistema Carcerário e do Sistema de Execução de Medidas Socioeducativas.

Brasil (2017). Levantamento nacional de informações penitenciárias atualização - junho de 2016. Technical report, Ministério da Justiça e Segurança Pública, Departamento Penitenciário Nacional.

Brasil (2019). Relatório de ações. Technical report.

de Franco, I., Marchezan, J. C., and Langenegger, N. (2015). Acesso à informação no tribunal de justiça de são paulo. Technical report, Associação Interlab de Pesquisa em Direito e Tecnologia.

Di Tella, R. and Schargrodsky, E. (2013). Criminal recidivism after prison and electronic monitoring. Journal of Political Economy, 121(1):28 - 73.

Dias, C. C. N. (2011). Estado e pcc em meio às tramas do poder arbitrário nas prisões. Tempo social, 23(2):213-233.

Dobbie, W., Goldin, J., and Yang, C. S. (2018). The effects of pretrial detention on conviction, future crime, and employment: Evidence from randomly assigned judges. American Economic Review, 108(2):201-40.

Godoi, R. (2016). PENAR EM SÃO PAULO: Sofrimento e mobilização na prisão contemporânea. Revista Brasileira de Ciências Sociais, 31.

Grogger, J. (1995). The effect of arrests on the employment and earnings of young men. The Quarterly Journal of Economics, 110(1):51-71.

Kling, J. R. (2006). Incarceration length, employment, and earnings. American Economic Review, 96(3):863-876.

Mueller-Smith, M. (2015). The criminal and labor market impacts of incarceration. Working paper, National Bureau of Economic Research. 
A

Statistics of São Paulo's Penitentiary System 
Table A.1: Information on São Paulo State prison population

\begin{tabular}{|c|c|c|}
\hline \multirow{3}{*}{ Summary } & "Total prison population (inmates) & 240,061 \\
\hline & Occupancy rate (population/capacity) & $183 \%$ \\
\hline & Male prisoners & $94 \%$ \\
\hline \multirow{5}{*}{ Detention Regime } & Pretrial & $32 \%$ \\
\hline & Closed regime & $53 \%$ \\
\hline & Semi-open regime & $15 \%$ \\
\hline & Open regime & $0 \%$ \\
\hline & Other & $1 \%$ \\
\hline \multirow{5}{*}{ Age Group } & 18 to 24 years old & $28 \%$ \\
\hline & 25 to 29 years old & $25 \%$ \\
\hline & 30 to 34 years old & $20 \%$ \\
\hline & 35 to 45 years old & $20 \%$ \\
\hline & More than 45 years old & $7 \%$ \\
\hline \multirow{3}{*}{ Race and ethnicity } & White & $44 \%$ \\
\hline & Black & $56 \%$ \\
\hline & Other & $0 \%$ \\
\hline \multirow{7}{*}{ Education } & Illiterate & $2 \%$ \\
\hline & Literate (with no formal education) & $3 \%$ \\
\hline & Incomplete primary school & $45 \%$ \\
\hline & Complete primary school & $17 \%$ \\
\hline & Incomplete secondary school & $19 \%$ \\
\hline & Complete secondary school & $12 \%$ \\
\hline & More than secondary school & $1 \%$ \\
\hline \multirow{5}{*}{ Class of crimes } & Drug related & $38 \%$ \\
\hline & Robbery & $34 \%$ \\
\hline & Theft & $15 \%$ \\
\hline & Homicide & $10 \%$ \\
\hline & Handling stolen goods & $3 \%$ \\
\hline \multirow{3}{*}{ Activities } & Inmates in education activities & $10 \%$ \\
\hline & Inmates in labour activities & $13 \%$ \\
\hline & $\begin{array}{l}\text { Proportion of inmates in labour activities } \\
\text { in external labour }\end{array}$ & $10 \%$ \\
\hline
\end{tabular}

Notes: Statistic information about São Paulo estate prison system. Collected with forms filled by managers of all prison facilities around the state, during June of 2016. Information was compiled and published by the Federal Ministry of Justice and Public Security (Brasil, 2017) 
B

Independence of the instrument 
Table B.1: Correlation between instrument and pre-trial characteristics - Crime Types
$(1)$
$(2)$
(3)
$(4)$

Dependent variable $\begin{gathered}\text { Coefficient } \\ \text { estimate }\end{gathered} \begin{gathered}\text { Standard } \\ \text { error }\end{gathered}$ P-value Observations

\begin{tabular}{|c|c|c|c|c|}
\hline \multicolumn{5}{|l|}{ A. Robbery } \\
\hline Employed = 1 & -0.003 & 0.010 & 0.768 & 101,791 \\
\hline Schooling & 0.117 & 0.097 & 0.229 & 17,674 \\
\hline Black $=1$ & -0.096 & 0.031 & 0.002 & 17,674 \\
\hline Age & 0.389 & 0.632 & 0.538 & 17,674 \\
\hline Wage $(\mathrm{R} \$)$ & -383.158 & 120.704 & 0.002 & 16,972 \\
\hline \multicolumn{5}{|l|}{ B. Drug-related } \\
\hline Employed = 1 & 0.010 & 0.012 & 0.414 & 73,616 \\
\hline Observations & 73,616 & & & 12,630 \\
\hline Schooling & 0.103 & 0.115 & 0.369 & 12,630 \\
\hline Black $=1$ & -0.029 & 0.036 & 0.431 & 12,630 \\
\hline Age & 0.859 & 0.737 & 0.244 & 12,630 \\
\hline Wage $(\mathrm{R} \$)$ & 477.904 & 140.366 & 0.001 & 12,174 \\
\hline \multicolumn{5}{|l|}{ C. Theft } \\
\hline Employed = 1 & -0.004 & 0.012 & 0.752 & 69,661 \\
\hline Schooling & -0.148 & 0.129 & 0.250 & 11,371 \\
\hline Black $=1$ & 0.047 & 0.039 & 0.225 & 11,371 \\
\hline Age & -1.331 & 0.839 & 0.113 & 11,371 \\
\hline Wage $(\mathrm{R} \$)$ & -272.510 & 154.791 & 0.078 & 10,958 \\
\hline \multicolumn{5}{|l|}{ D. Stolen goods } \\
\hline Employed = 1 & 0.045 & 0.018 & 0.013 & 34,550 \\
\hline Schooling & 0.584 & 0.183 & 0.001 & 6,059 \\
\hline Black $=1$ & -0.084 & 0.056 & 0.138 & 6,059 \\
\hline Age & -2.069 & 1.201 & 0.085 & 6,059 \\
\hline Wage $(\mathrm{R} \$)$ & 769.533 & 230.735 & 0.001 & 5,863 \\
\hline Observations & 6,059 & & & \\
\hline \multicolumn{5}{|l|}{ E. Firearm } \\
\hline Employed = 1 & -0.013 & 0.028 & 0.630 & 15,955 \\
\hline Schooling & -0.469 & 0.232 & 0.043 & 3,453 \\
\hline Black $=1$ & -0.011 & 0.069 & 0.875 & 3,453 \\
\hline Age & -1.158 & 1.584 & 0.465 & 3,453 \\
\hline Wage $(\mathrm{R} \$)$ & -955.394 & 504.279 & 0.058 & 3,383 \\
\hline
\end{tabular}

Note: Correlation between the instrument incarceration propensity and other characteristics, only available in RAIS, evaluated before the trial. The number of observations vary depending on the dependent variable pretrial availability. 
C

\section{Monotonicity}

Table C.1: Monotonicity assumption test

(1)

(2)

(3)

(4)

(5)
A. Crime types
Robbery
Drug-related
Theft Stolen
Firearm
Dependent variable: convicted $=1$
$Z_{I P}$
$0.681^{* * *}$
$1.224^{* * *}$
$0.717^{* * *} \quad 0.620^{* * *}$
$0.518^{* * *}$
$(0.022)$
$(0.031)$
$(0.031) \quad(0.044)$
$(0.059)$

Dependent variable: prison sentence in years

$\begin{array}{lccccc}Z_{P S} & 0.949^{* * *} & 1.477^{* * *} & 0.300^{* * *} & 0.297^{* * *} & 0.394^{* * *} \\ & (0.036) & (0.041) & (0.012) & (0.021) & (0.047) \\ \text { Observations } & 22,214 & 16,278 & 15,167 & 7,331 & 3,702\end{array}$

B. Name frequency

Less frequent More frequent

Dependent variable: convicted $=1$
$Z_{I P}$

$$
\begin{array}{cc}
0.813^{* * *} & 0.985^{* * *} \\
(0.018) & (0.030)
\end{array}
$$

Dependent variable: prison sentence in years

\begin{tabular}{lcc}
$Z_{P S}$ & $0.749^{* * *}$ & $0.922^{* * *}$ \\
& $(0.020)$ & $(0.034)$ \\
Observations & 45,663 & 19,059 \\
\hline
\end{tabular}

Note: Simple linear regression of reverse-sample instrument which excludes own-type cases when calculating mean incarceration propensity and mean prison sentence. No controls are included. Standard errors in parentheses, ${ }^{*} \mathrm{p}<0.05,{ }^{*} \mathrm{p}<0.01,{ }^{* * *}$ $\mathrm{p}<0.001$ 
D

First stage results 
Table D.1: First stage results - Robbery

\begin{tabular}{|c|c|c|c|c|}
\hline & $\begin{array}{c}(1) \\
\text { Prison }_{t 0}\end{array}$ & $\begin{array}{c}(2) \\
\text { Release }_{t 0}\end{array}$ & $\begin{array}{c}(3) \\
\text { convicted=1 }\end{array}$ & $\begin{array}{c}(4) \\
\text { prison sentence }\end{array}$ \\
\hline$Z_{I P}$ & & & $\begin{array}{c}0.836^{* * *} \\
(0.024)\end{array}$ & \\
\hline$Z_{P S}$ & & & & $\begin{array}{c}1.078^{* * *} \\
(0.034)\end{array}$ \\
\hline$J_{t 0}$ & $\begin{array}{c}0.278^{* * *} \\
(0.008)\end{array}$ & $\begin{array}{c}0.030^{* *} \\
(0.011)\end{array}$ & & \\
\hline$J_{t+1}$ & $\begin{array}{l}-0.011 \\
(0.010)\end{array}$ & $\begin{array}{c}0.241^{* * *} \\
(0.011)\end{array}$ & & \\
\hline$Z_{I P} \cdot J_{t 0}$ & $\begin{array}{c}0.833^{* * *} \\
(0.014)\end{array}$ & $\begin{array}{c}0.129^{* *} \\
(0.041)\end{array}$ & & \\
\hline$Z_{I P} \cdot J_{t+1}$ & $\begin{array}{l}0.015 \\
(0.017)\end{array}$ & $\begin{array}{c}0.613^{* * *} \\
(0.044)\end{array}$ & & \\
\hline$Z_{I P} \cdot J_{t+2}$ & $\begin{array}{l}-0.011 \\
(0.019)\end{array}$ & $\begin{array}{c}0.517^{* * *} \\
(0.050)\end{array}$ & & \\
\hline$Z_{I P} \cdot J_{t+3}$ & $\begin{array}{l}-0.007 \\
(0.022)\end{array}$ & $\begin{array}{c}-0.263^{* * *} \\
(0.060)\end{array}$ & & \\
\hline$Z_{P S} \cdot J_{t 0}$ & & $\begin{array}{c}-0.021^{* *} \\
(0.008)\end{array}$ & & \\
\hline$Z_{P S} \cdot J_{t+1}$ & & $\begin{array}{c}-0.134^{* * *} \\
(0.008)\end{array}$ & & \\
\hline$Z_{P S} \cdot J_{t+3}$ & & $\begin{array}{c}0.096^{* * *} \\
(0.011)\end{array}$ & & \\
\hline Observations & 177,952 & 177,952 & 22,244 & 22,214 \\
\hline F-statistic & 20,479 & 5,277 & 9,720 & 2,542 \\
\hline $\mathrm{R}^{2}$ & 0.767 & 0.556 & 0.052 & 0.042 \\
\hline $\mathrm{R}^{2}$ within & 0.767 & 0.556 & & \\
\hline $\mathrm{R}^{2}$ between & 0.421 & 0.486 & & \\
\hline $\mathrm{R}^{2}$ overall & 0.653 & 0.533 & & \\
\hline $\begin{array}{l}\text { F-test exclusion } \\
\text { of instruments }\end{array}$ & 0.000 & 0.000 & 0.000 & 0.000 \\
\hline
\end{tabular}

Note: Columns 1 and 2 present robbery subsample estimates from first stage model presented in equation 4-5 for prison and equation 4-6 for release treatment. Regressions include individual fixed-effects and time fixed effects. Only coefficients statistically different from zero, with $95 \%$ confidence, are reported. Columns 3 and 4 present a pseudo first stage, showing the correlation between endogenous variable and instrument. Standard errors in parentheses, ${ }^{*} \mathrm{p}<0.05,{ }^{*} \mathrm{p}<0.01,{ }^{* * *} \mathrm{p}<0.001$ 
Table D.2: First stage results - Drug-related

\begin{tabular}{|c|c|c|c|c|}
\hline & $\begin{array}{c}(1) \\
\text { Prison }_{t 0}\end{array}$ & $\begin{array}{c}(2) \\
\text { Release } t 0\end{array}$ & $\begin{array}{c}(3) \\
\text { convicted=1 }\end{array}$ & $\begin{array}{c}(4) \\
\text { prison sentence }\end{array}$ \\
\hline$Z_{I P}$ & & & $\begin{array}{c}1.343^{* * *} \\
(0.027)\end{array}$ & \\
\hline$Z_{P S}$ & & & & $\begin{array}{c}1.520^{* * *} \\
(0.034)\end{array}$ \\
\hline$J_{t 0}-0.040 * * *$ & $\begin{array}{l}0.026 * \\
(0.009)\end{array}$ & $(0.012)$ & & \\
\hline$J_{t+2}$ & $\begin{array}{c}0.014 \\
(0.013)\end{array}$ & $\begin{array}{c}-0.0666^{* * *} \\
(0.015)\end{array}$ & & \\
\hline$Z_{I P} \cdot J_{t 0}$ & $\begin{array}{c}1.352^{* * *} \\
(0.016)\end{array}$ & $\begin{array}{c}0.578 * * * \\
(0.047)\end{array}$ & & \\
\hline$Z_{I P} \cdot J_{t+1}$ & $\begin{array}{c}0.022 \\
(0.019) \\
(0.019)\end{array}$ & $\begin{array}{c}1.562 \text { *** } \\
(0.050) Z_{I P} \cdot J_{t+2} \\
(0.050)\end{array}$ & -0.011 & $0.517^{* * *}$ \\
\hline$Z_{I P} \cdot J_{t+3}$ & $\begin{array}{l}-0.013 \\
(0.024)\end{array}$ & $\begin{array}{c}-0.406 * * * \\
(0.069)\end{array}$ & & \\
\hline$Z_{P S} \cdot J_{t 0}$ & & $\begin{array}{c}-0.110 * * * \\
(0.009)\end{array}$ & & \\
\hline$Z_{P S} \cdot J_{t+1}$ & & $\begin{array}{c}-0.256 \text { *** } \\
(0.010)\end{array}$ & & \\
\hline$Z_{P S} \cdot J_{t+2}$ & & $\begin{array}{c}0.134 * * * \\
(0.011)\end{array}$ & & \\
\hline$Z_{P S} \cdot J_{t+3}$ & & $\begin{array}{c}0.122 * * * \\
(0.013)\end{array}$ & & \\
\hline Year $=2017$ & $\begin{array}{c}-0.037 * * * \\
(0.011)\end{array}$ & $\begin{array}{l}-0.009 \\
(0.016)\end{array}$ & & \\
\hline Observations & 130,224 & 130,224 & 16,278 & 16,278 \\
\hline F-statistic & 14,806 & 4,247 & 9,720 & 2,542 \\
\hline $\mathrm{R}^{2}$ & 0.765 & 0.580 & 0.127 & 0.111 \\
\hline $\mathrm{R}^{2}$ between & 0.476 & 0.521 & & \\
\hline $\mathrm{R}^{2}$ within & 0.765 & 0.580 & & \\
\hline $\mathrm{R}^{2}$ overall & 0.663 & 0.560 & & \\
\hline $\begin{array}{l}\text { F-test exclusion } \\
\text { of instruments }\end{array}$ & 0.000 & 0.000 & 0.000 & 0.000 \\
\hline
\end{tabular}

Note: Columns 1 and 2 present drug-related subsample estimates from first stage model presented in equation 4-5 for prison and equation 4-6 for release treatment. Regressions include individual fixed-effects and time fixed effects. Only coefficients statistically different from zero, with $95 \%$ confidence, are reported. Columns 3 and 4 present a pseudo first stage, showing the correlation between endogenous variable and instrument. Standard errors in parentheses, ${ }^{*} \mathrm{p}<0.05,{ }^{*} \mathrm{p}<0.01,{ }^{* * *} \mathrm{p}<0.001$ 
Table D.3: First stage results - Theft

\begin{tabular}{|c|c|c|c|c|}
\hline & $\begin{array}{c}(1) \\
\text { Prison }_{t 0}\end{array}$ & $\begin{array}{c}(2) \\
\text { Release }_{t 0}\end{array}$ & $\begin{array}{c}(3) \\
\text { convicted }=1\end{array}$ & $\begin{array}{c}(4) \\
\text { prison sentence }\end{array}$ \\
\hline$Z_{I P}$ & & & $\begin{array}{c}0.830^{* * *} \\
(0.032)\end{array}$ & \\
\hline$Z_{P S}$ & & & & $\begin{array}{c}0.368^{* * *} \\
(0.014)\end{array}$ \\
\hline$J_{t 0}$ & $\begin{array}{c}-0.139^{* * *} \\
(0.011)\end{array}$ & $\begin{array}{c}0.003 \\
(0.013)\end{array}$ & & \\
\hline$J_{t+1}$ & $\begin{array}{l}-0.001 \\
(0.013)\end{array}$ & $\begin{array}{c}-0.117^{* *} \\
(0.013)\end{array}$ & & \\
\hline$Z_{I P} \cdot J_{t 0}$ & $\begin{array}{c}0.833^{* * *} \\
(0.019)\end{array}$ & $\begin{array}{c}0.655^{* * *} \\
(0.047)\end{array}$ & & \\
\hline$Z_{I P} \cdot J_{t+1}$ & $\begin{array}{l}-0.009 \\
(0.022)\end{array}$ & $\begin{array}{c}0.134^{* *} \\
(0.051)\end{array}$ & & \\
\hline$Z_{P S} \cdot J_{t 0}$ & & $\begin{array}{c}-0.085^{* *} \\
(0.009)\end{array}$ & & \\
\hline$Z_{P S} \cdot J_{t+1}$ & & $\begin{array}{l}0.078^{* *} \\
(0.010)\end{array}$ & & \\
\hline Observations & 121,336 & 121,336 & 15,167 & 15,167 \\
\hline F-statistic & 2,393 & 1,199 & 9,720 & 2,542 \\
\hline $\mathrm{R}^{2}$ & 0.360 & 0.295 & 0.127 & 0.111 \\
\hline $\mathrm{R}^{2}$ between & 0.131 & 0.146 & & \\
\hline $\mathrm{R}^{2}$ within & 0.360 & 0.295 & & \\
\hline $\mathrm{R}^{2}$ overall & 0.252 & 0.228 & & \\
\hline $\begin{array}{l}\text { F-test exclusion } \\
\text { of instruments }\end{array}$ & 0.000 & 0.000 & 0.000 & 0.000 \\
\hline
\end{tabular}

Note: Columns 1 and 2 present theft subsample estimates from first stage model presented in equation 4-5 for prison and equation 4-6 for release treatment. Regressions include individual fixed-effects and time fixed effects. Only coefficients statistically different from zero, with $95 \%$ confidence, are reported. Columns 3 and 4 present a pseudo first stage, showing the correlation between endogenous variable and instrument. Standard errors in parentheses, ${ }^{*} \mathrm{p}<0.05,{ }^{* *} \mathrm{p}<0.01,{ }^{* * *} \mathrm{p}<0.001$ 
Table D.4: First stage results - Stolen goods

\begin{tabular}{|c|c|c|c|c|}
\hline & $\begin{array}{c}(1) \\
\text { Prison }_{t 0}\end{array}$ & $\begin{array}{c}(2) \\
\text { Release }_{t 0}\end{array}$ & $\begin{array}{c}(3) \\
\text { convicted=1 }\end{array}$ & $\begin{array}{c}(4) \\
\text { prison sentence }\end{array}$ \\
\hline$Z_{I P}$ & & & $\begin{array}{c}0.679^{* * *} \\
(0.045)\end{array}$ & \\
\hline$Z_{P S}$ & & & & $\begin{array}{c}0.326^{* * *} \\
(0.022)\end{array}$ \\
\hline$J_{t 0}$ & $\begin{array}{c}-0.089^{* * *} \\
(0.016)\end{array}$ & $\begin{array}{l}-0.004 \\
(0.018)\end{array}$ & & \\
\hline $\begin{array}{l}J_{t+1} \\
(0.019)\end{array}$ & $\begin{array}{c}0.009 \\
(0.019)\end{array}$ & $-0.044^{*}$ & & \\
\hline$Z_{I P} \cdot J_{t 0}$ & $\begin{array}{c}0.681^{* * *} \\
(0.026)\end{array}$ & $\begin{array}{c}0.412^{* * *} \\
(0.067)\end{array}$ & & \\
\hline$Z_{I P} \cdot J_{t+1}$ & $\begin{array}{l}-0.015 \\
(0.032)\end{array}$ & $\begin{array}{l}-0.156^{*} \\
(0.072)\end{array}$ & & \\
\hline$Z_{P S} \cdot J_{t 0}$ & $-0.037^{* *}$ & $(0.013)$ & & \\
\hline$Z_{P S} \cdot J_{t 1}$ & $\begin{array}{c}0.109^{* * *} \\
(0.014)\end{array}$ & & & \\
\hline Observations & 58,648 & 58,648 & 7,331 & 7331 \\
\hline F-statistic & 940 & 478 & 224 & 214 \\
\hline $\mathrm{R}^{2}$ & 0.314 & 0.256 & 0.030 & 0.028 \\
\hline $\mathrm{R}^{2}$ between & 0.110 & 0.123 & & \\
\hline $\mathrm{R}^{2}$ within & 0.314 & 0.256 & & \\
\hline $\mathrm{R}^{2}$ overall & 0.220 & 0.199 & & \\
\hline $\begin{array}{l}\text { F-test exclusion } \\
\text { of instruments }\end{array}$ & 0.000 & 0.000 & 0.000 & 0.000 \\
\hline
\end{tabular}

Note: Columns 1 and 2 present handling of stolen goods subsample estimates from first stage model presented in equation 4-5 for prison and equation 4-6 for release treatment. Regressions include individual fixed-effects and time fixed effects. Only coefficients statistically different from zero, with $95 \%$ confidence, are reported. Columns 3 and 4 present a pseudo first stage, showing the correlation between endogenous variable and instrument. Standard errors in parentheses, ${ }^{*} \mathrm{p}<0.05$, ${ }^{* *} \mathrm{p}<0.01,{ }^{* * *} \mathrm{p}<0.001$ 
Table D.5: First stage results - Firearm

\begin{tabular}{|c|c|c|c|c|}
\hline & $\begin{array}{c}(1) \\
\text { Prison }_{t 0}\end{array}$ & $\begin{array}{c}(2) \\
\text { Release }_{t 0}\end{array}$ & $\begin{array}{c}(3) \\
\text { convicted=1 }\end{array}$ & $\begin{array}{c}(4) \\
\text { prison sentence }\end{array}$ \\
\hline$Z_{I P}$ & & & $\begin{array}{c}0.545^{* * *} \\
(0.060)\end{array}$ & \\
\hline$Z_{P S}$ & & & & $\begin{array}{c}0.418^{* * *} \\
(0.048)\end{array}$ \\
\hline$J_{t 0}$ & $\begin{array}{c}-0.044^{*} \\
(0.021)\end{array}$ & $\begin{array}{l}-0.003 \\
(0.023)\end{array}$ & & \\
\hline$J_{t+1}$ & $\begin{array}{c}0.559^{* * *} \\
(0.035)\end{array}$ & $\begin{array}{c}0.092 \\
(0.087)\end{array}$ & & \\
\hline$Z_{I P} \cdot J_{t 0}$ & $\begin{array}{l}-0.008 \\
(0.042)\end{array}$ & $\begin{array}{l}0.239^{*} \\
(0.092)\end{array}$ & & \\
\hline$Z_{I P} \cdot J_{t+1}$ & $\begin{array}{l}-0.015 \\
(0.032)\end{array}$ & $\begin{array}{c}-0.156^{*} \\
(0.072)\end{array}$ & & \\
\hline$Z_{P S} \cdot J_{t 0}$ & $\begin{array}{c}-0.037 * * \\
(0.013)\end{array}$ & & & \\
\hline$Z_{P S} \cdot J_{t 1}$ & $\begin{array}{c}0.109 \text { *** } \\
(0.014)\end{array}$ & & & \\
\hline Observations & 29,616 & 29,616 & 3,702 & 3,702 \\
\hline F-statistic & 427 & 208 & 81 & 76 \\
\hline $\mathrm{R}^{2}$ & 0.292 & 0.229 & 0.022 & 0.020 \\
\hline $\mathrm{R}^{2}$ between & 0.069 & 0.095 & & \\
\hline $\mathrm{R}^{2}$ within & 0.292 & 0.229 & & \\
\hline $\mathrm{R}^{2}$ overall & 0.180 & 0.170 & & \\
\hline $\begin{array}{l}\text { F-test exclusion } \\
\text { of instruments }\end{array}$ & 0.000 & 0.000 & 0.000 & 0.000 \\
\hline
\end{tabular}

Note: Columns 1 and 2 present handling of firearm subsample estimates from first stage model presented in equation 4-5 for prison and equation 4-6 for release treatment. Regressions include individual fixed-effects and time fixed effects. Only coefficients statistically different from zero, with $95 \%$ confidence, are reported. Columns 3 and 4 present a pseudo first stage, showing the correlation between endogenous variable and instrument. Standard errors in parentheses, ${ }^{*} \mathrm{p}<0.05$, ${ }^{* *} \mathrm{p}<0.01,{ }^{* * *} \mathrm{p}<0.001$ 
E

\section{Extra results - Figures}

Figure E.1: Handling of stolen goods DD results

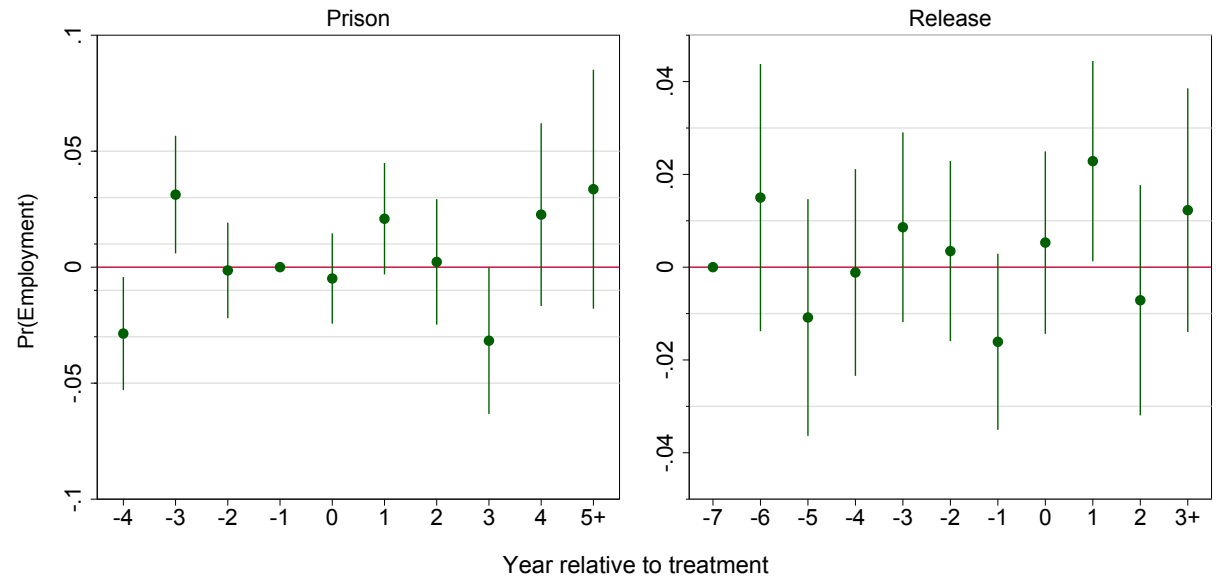

Figure E.2: Firearm possession DD results

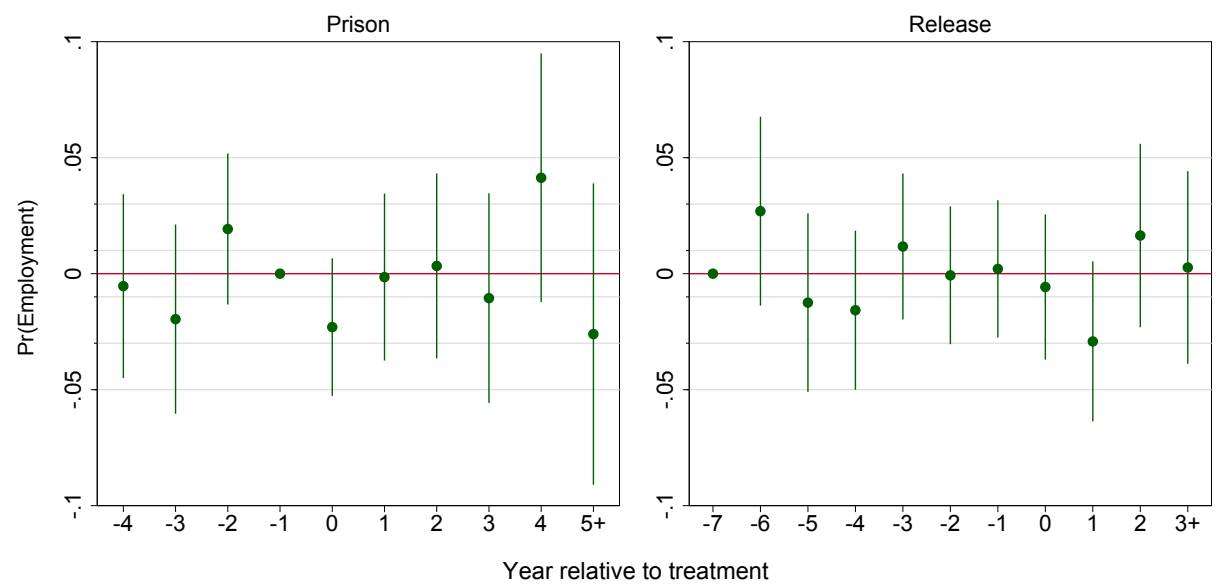


Figure E.3: Handling of stolen goods DD-IV results

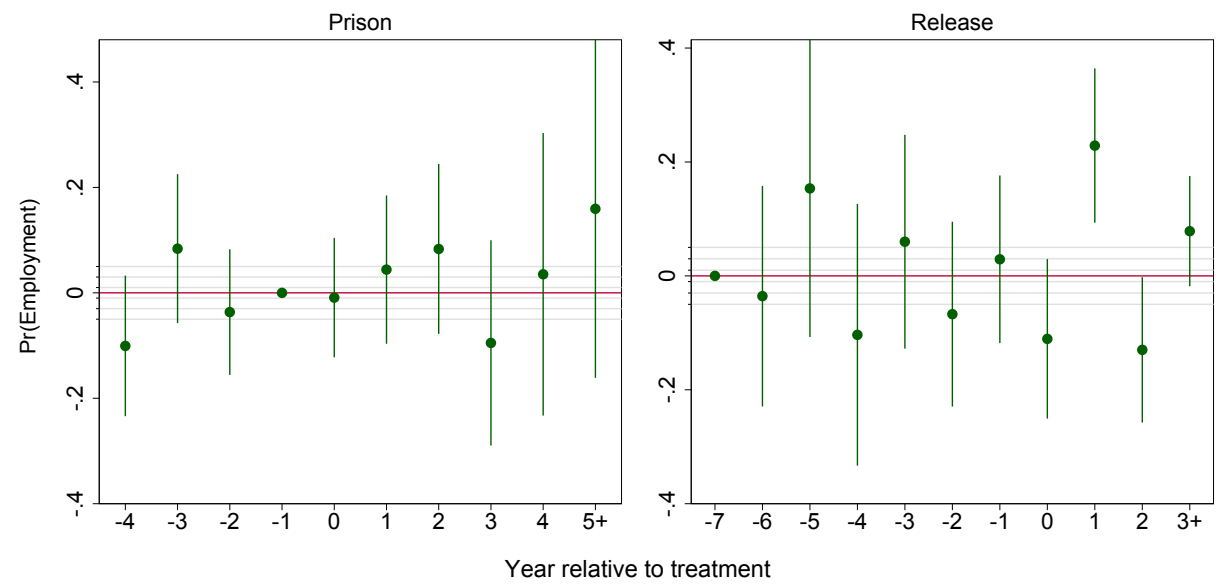

Uీ

Figure E.4: Firearm possession DD-IV results

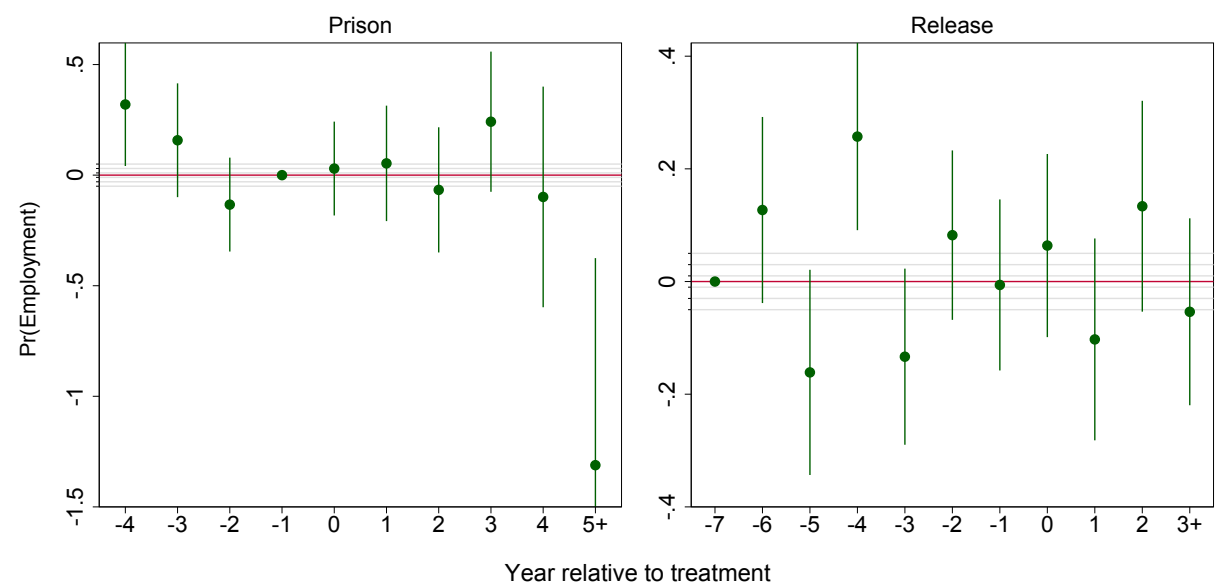

